\title{
Morocco: Report on Observance of Standards and Codes- Fiscal Transparency Module
}

This Report on the Observance of Standards and Codes on Fiscal Transparency for Morocco was prepared by a staff team of the International Monetary Fund as background documentation for the periodic consultation with the member country. It is based on the information available at the time it was completed on August 2, 2005. The views expressed in this document are those of the staff team and do not necessarily reflect the views of the government of Morocco or the Executive Board of the IMF.

The policy of publication of staff reports and other documents by the IMF allows for the deletion of market-sensitive information.

To assist the IMF in evaluating the publication policy, reader comments are invited and may be sent by e-mail to publicationpolicy@imf.org.

Copies of this report are available to the public from

International Monetary Fund $\bullet$ Publication Services

700 19th Street, N.W. • Washington, D.C. 20431

Telephone: (202) $6237430 \bullet$ Telefax: (202) 6237201

E-mail: publications@imf.org • Internet: http://www.imf.org

Price: $\$ 15.00$ a copy

\section{International Monetary Fund \\ Washington, D.C.}





\section{INTERNATIONAL MONETARY FUND \\ MOROCCO \\ Report on the Observance of Standards and Codes (ROSC) Fiscal Transparency Module}

Prepared by the Fiscal Affairs Department

Approved by Mohsin S. Khan and Teresa Ter-Minassian

August 2, 2005

\section{EXECUTIVE SUMMARY}

This report evaluates Morocco's fiscal transparency practices and assesses compliance with the IMF's Code of Good Practices on Fiscal Transparency, on the basis of interviews with the authorities and other interlocutors, the authorities' replies to the IMF questionnaire on fiscal transparency, as well as other sources of information. Further explanation of the terms and concepts used in this report can be found in the IMF's Manual on Fiscal Transparency (http://www.imf.org/external/np/fad/trans/manual).

Morocco's fiscal management system, which remains highly centralized and focused on strict controls to ensure that expenditure items are correct, is essentially reliable and supported by legal safeguards, and adequate for steering budget performance. The far-reaching amendment of the organic law governing budget laws carried out in November 1998, the legislative and regulatory provisions that accompanied it, and the recent reforms have led to significant progress with respect to the clarity of fiscal and accounting standards, access to financial information, control over the processes involved in preparing and executing expenditure, and the quality of financial data. Thanks to these transformations, today fiscal transparency is, for the most part, guaranteed. However, despite the generally satisfactory overall picture, progress is still needed in several areas if Morocco's fiscal management is to meet the transparency standards of international best practices. Top priority improvements, which may be accomplished in the short term, have to do with gradual expansion of budget coverage and monitoring to include general government, modernizing government accounting, improving financial reporting during execution of the budget law, and evaluation of fiscal risks. Longer-term reforms should aim at introducing performance-oriented public management and reducing emphasis on ex ante controls, once stronger ex post evaluation and controls have been achieved. 


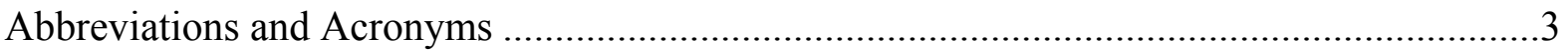

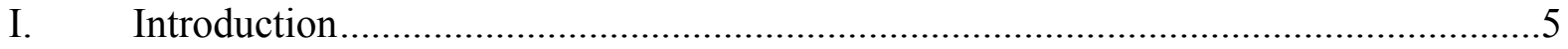

II. Description of Practices ................................................................................

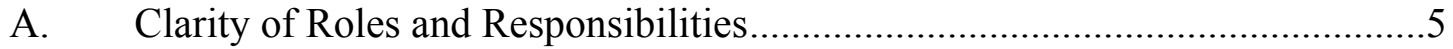

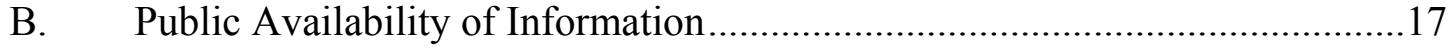

C. Open Budget Preparation, Execution, and Reporting ................................23

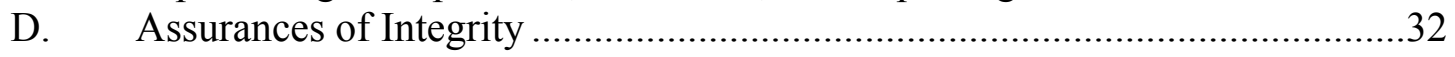

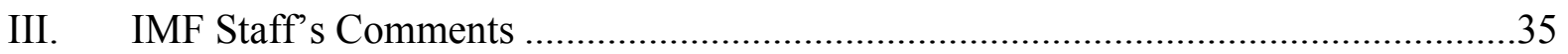

Tables

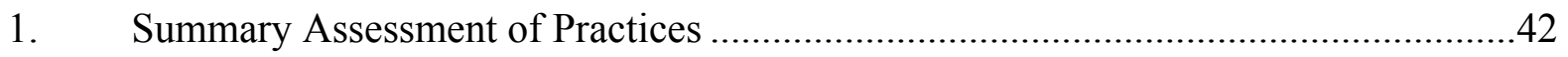

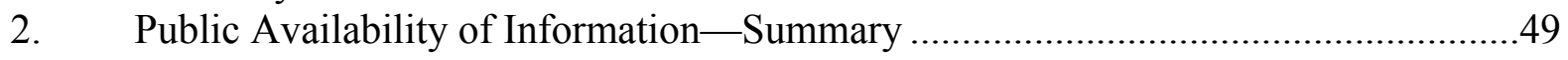

Boxes

1 General Government in the Kingdom of Morocco ................................................6

$2 \quad$ The Hassan II Fund ....................................................................................... 7

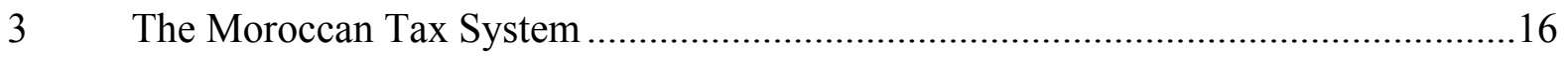

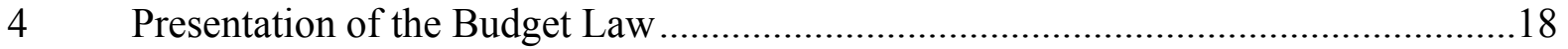

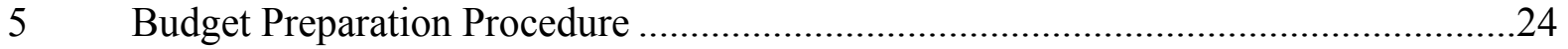




\section{AbBreviations AND ACRONYMS}

AC Administrations centrales [Central Government]

ADDI

Administration des Douanes et Droits Indirects [Customs and Indirect Taxes]

ADM

Autoroutes du Maroc [National Company of Moroccan Highways]

APU

Administrations publiques [General Government]

BA

Budget annexe [Annex autonomous budget]

BAM

Bank al Maghrib [the Moroccan central bank]

BNDE

CAM

Banque Nationale de Développement Economique

CBMT

Crédit Agricole du Maroc

CCI

Cadre budgétaire à moyen terme [Medium-term fiscal framework]

$\mathrm{CDE}$

Commission Consultative des Importations [Advisory Committee on Imports]

$\mathrm{CDG}$

Contrôles des Dépenses Engagées \{Expenditure audits)

$\mathrm{CIH}$

Caisse de Dépôt et de Gestion

CLT

Crédit Immobilier et Hôtelier

$\mathrm{CNC}$

Commission Locale de Taxation [Local taxation committee]

CNRF

Conseil National de la Comptabilité [National Accounting Council]

CNSS

Commission Nationale de Recours Fiscal [National Tax Appeal Committee]

COMANAV Compagnie Mar

CST Comptes Spéciaux du Trésor [Special treasury accounts]

DEPP

Direction des Entreprises Publiques et de la Privatisation [Directorate of

Public Enterprises and Privatization]

DGI

$\mathrm{DH}$

Direction Générale des Impôts [General Directorate of Taxes]

DPEG

Dirhams (Morocco's currency)

DTFE

Direction de la Politique Economique Générale [Directorate of Economic

Policy]

Direction du Trésor et des
and External Financing]

EEP Etablissements et entreprises publiques [Public establishments and enterprises]

EPA Public administrative establishments

EPIC Public industrial and commercial establishments

GFS Government Finance Statistics

GFSM Government Financial Statistics Manual

GID

Gestion Informatisée des Données [Automated data management]

GID

IGR

IMF

IS

Gestion Intégrée de la Dépense [Integrated Expenditure Management]

LO

MFP Impôt Général sur le Revenu [General income tax]

International Monetary Fund

Impôt sur les Sociétés [Corporate tax]

Loi organique relative aux lois de finances [Organic law governing budget laws]

ODAC Organismes Divers d'Administration Centrale [Miscellaneous agencies of the central government] 
ONCF Office National des Chemins de Fer [National Railways Office]

OSS

Organismes de Sécurité Sociale [Social security agencies]

QFAs

Quasi-fiscal activities

RAM

Royal Air Maroc

RCAR

Régime Collectif d'Allocations Retraite [Pension Fund]

ROSC

Report on the Observance of Standards and Codes

RTM

Radio Télévision Marocaine

SDDS

Special Data Dissemination Standard

SEGMA

Services de l'Etat gérés de manière autonome [Government services run independently]

SGFP Statut Général de la Fonction Publique [General Statute of the Civil Service]

SNA System of National Accounts

SUTA Sucreries de Tadla [Tadla sugar refineries]

TGR Trésorerie Générale du Royaume [General Treasury of the Kingdom]

TIC Taxes intérieures de consummation [Domestic consumption taxes]

VAT Value-added tax

\section{Morocco: Basic data}

Type of government: Constitutional monarchy

Fiscal year: Calendar year (since 2001)

Population (most recent year): 30.5 million (2004)

GDP (most recent year): 443.7 billion dirhams (DH) (2004 estimate)

Debt/GDP (most recent year) : 66.0 percent of GDP 


\section{INTRODUCTION ${ }^{1}$}

This report evaluates Morocco's fiscal transparency practices and assesses compliance with the IMF's Code of Good Practices on Fiscal Transparency. This evaluation is divided into two parts. The first describes current practices with regard to transparency. It was prepared by IMF staff, based on interviews with the authorities and their replies to the questionnaire on fiscal transparency, and on other available sources of information. The second part consists of commentary by IMF staff on fiscal transparency in Morocco.

\section{Description of Practices}

\section{A. Clarity of Roles and Responsibilities}

\section{Definition of general government activities}

1. National System of Accounts statistics define the general government 1.1 .1 sector in accordance with the Government Financial Statistics Manual of 2001 (GFSM 2001). However, general government activities are not clearly defined, as fiscal data are only consolidated at the central government level. The boundaries of general government used by the Office of the High Commissioner for Planning ${ }^{2}$ in order to draw up national account statistics correspond to the definitions contained in the 1993 System of National Accounts and GFSM (see Box 1). General government comprises central government and its divisions (the various ministries with their central and decentralized departments, the Radiotélévision Marocaine's annex autonomous budget, independently run government services, and the Special Treasury Accounts), the mandatory social security funds, local governments, and national nonmarket public establishments. ${ }^{3}$ This last category comprises 220 legally autonomous entities, supervised and run by the government, and financed both by government subsidies and their own resources. These are principally educational institutions (schools and universities), hospitals (in addition to those already listed under SEGMA), chambers of commerce and professionals. Since the end of 2002 the Hassan II Fund for Economic and Social Development has been included in the category of the non-market and non-profit institutions (see Box 2).

\footnotetext{
${ }^{1}$ The interviews on fiscal transparency were conducted in Rabat from June 28 to July 7, 2004. An IMF staff team comprising Messrs. Lazare (head), Kalfon (both from the Fiscal Affairs Department, FAD), Dumas and Guiraud (member of the FAD panel of experts) interviewed Their Excellencies, the Ministers of Finance and Privatization, Social Development, the Family and Solidarity, as well as the Governor of Bank Al-Maghrib, the First President of the Audit Office, the High Commissioner for Planning (Haut Commissaire au Plan), and a number of senior officials, including the Secretary General of the Ministry of Finance and Privatization, the Director of the Treasury and External Financing, the Director of the Budget, the Treasurer General of the Kingdom, the Director of General Control for Expenditure Commitments, and the Inspector General of Finance. The team also met with officials of financial and nonfinancial government agencies, as well as representatives of Moroccan private sector employers.

${ }^{2} \mathrm{http}: / /$ www.statistic.gov.ma/

${ }^{3}$ Public administrative establishments, although the distinction between them and public industrial and commercial establishments is not based on precise legal rules.
} 


\section{Box 1. General Government in the Kingdom of Morocco}

General government comprises the following institutions:

\section{Central government units included in the budget}

1. Public administration units comprising the Royal Court, the two chambers of parliament, the financial tribunals, the prime minister's offices, 28 ministries (central government agencies and their local departments), and 3 High Commissions (planning, former combatants, and forestry).

2. One annex autonomous budget (Moroccan radio and television).

3. 159 government services run independently (SEGMA): mainly educational institutions and hospitals.

4. 97 Special Treasury Accounts classified in six categories:

- Special earmarking (including the fund for tax revenue collected on behalf of local governments, price support fund, special road network fund, and housing solidarity fund).

- Membership of international organizations.

- Monetary operations.

- Advances

- $\quad$ Loans

- $\quad$ Expenditures in the form of allowances (Dépenses sur dotations).

Non-budget central government units (extrabudgetary funds)

5. Social security agencies (OSS).

5.1 Caisse Marocaine de Retraites (civilian and military pensions for civil servants and local government officials).

5.2 Régime Collectif d'Allocations de Retraites (pensions of employees of government establishments and enterprises and non-career government staff).

5.3 Caisse Nationale de Sécurité Sociale (basic pension of private sector wage-earners).

5.4 Caisse Nationale des Organismes de Prévoyance Sociale (federation of mutual health insurance companies for civil servants).

6. Some 20 mutual health insurance companies for private sector wage-earners.

7. 220 national public administrative establishments: universities and educational institutions, farmers' and professional associations, regional hospitals not included in the SEGMA, and the Hassan II Fund for Economic and Social Development.

\section{Decentralized government units}

8. 16 regions.

9. 26 préfectures and 45 provinces.

10. 1,298 rural districts (communes) and 249 urban districts. 


\section{Box 2: The Hassan II Fund}

The Hassan II Fund was established in 2000, in the form of a Special Treasury Account (Decree 2-00-19 of March 16, 2000, subsequently ratified by the parliament in the budget law for the second semester of 2000), to tap part of the privatization receipts and use them to finance economic and social projects. The funds collected currently total over DH 19 billion, following three privatizations: $2^{\text {nd }}$ GSM telephone license, Maroc Télécom, and Régie des Tabacs.

A law passed at end-2002 converted the Fund into a public establishment (établissement public), classified as "administrative" by the Directorate of Public Enterprises and Privatizations (DEPP). In line with the practice followed for other établissements publics, the Hassan II Fund's operations are not included in the annual budget law approved by parliament. However, brief information on these operations is presented in the report on public enterprises and institutions annexed to the annual budget law, as well as in the note presenting the draft budget law and in various documents provided to parliament in the context of the discussions with the finance committees of the two chambers of parliament.

The Fund's managers were appointed in March 2003 and the funds transferred on July 8, 2003. These funds have been lodged partly with the General Treasury (approximately DH 2 billion) and, for the most part (approximately DH14 billion), with BAM, which pays interest of 2.3 percent.

The public establishment has an Executive Board, chaired by the Prime Minister and consisting of seven members (six ministers and the governor of the central bank). The Board draws up the budget, decides on programs, and adopts agreements. A Board of Directors, whose members are to be appointed by the King (to date only the Chairman has been appointed), sees to day-to-day management. The staff currently consists of 10 persons, six of whom are executives. The establishment's finances are supervised by the DEPP. The accounts were audited for the first time by an outside firm for the year ended December 31, 2003.

Some thought is currently being given to the Hassan II Fund's strategy. In particular, the idea is to garner alternative resources with a view to perpetuating the Fund once privatization receipts are exhausted or begin to slow down. The ways in which the Fund intervenes (subsidies, loans, equity holdings...) have still to be defined. Nevertheless, the establishment has already entered into 86 agreements (as of February 4, 2004), with a total commitment on the order of DH13 billion, distributed among the following sectors:

- $\quad$ Large-scale infrastructure: 50.5 percent

- $\quad$ Support for industrial investment: 20.6 percent

- $\quad$ Social sector (housing): 28.9 percent

Three large-scale operations may be cited: (1) Autoroutes du Maroc: equity holding of DH1.1 billion; (2) Marakkech-Agadir highway: equity holding of DH 1.5 billion; and (3) Port of Tangiers: nonreimbursable advance of DH 2 billion.

However, fiscal data are only consolidated at the central government level (excluding nonmarket nonprofit institutions and social security agencies):

- $\quad$ The budget law passed by parliament covers the central and external departments of ministries, the annex autonomous budgets, the SEGMA and the Special Treasury Accounts (CST), but does not address social security fund operations or public administrative establishments. In particular, the transactions of the Hassan II Fund are not included in the annual budget law and the overall balance of the central government does not record them. 
- $\quad$ This same boundary is used in the monthly government revenue and expenditure table, ${ }^{4}$ which is now the principal source of information on the fiscal position for the current year.

- The annual report on public establishments and enterprises does not clearly separate the activities of nonmarket public establishments, which - unlike those of marketoriented public establishments or public industrial and commercial establishments (EPIC) - should be included in the general government sector: it lumps together all public establishments and enterprises ${ }^{5}$ and, within public establishments, only partially distinguishes between market and nonmarket establishments. ${ }^{6}$

- $\quad$ The accounting statements on the consolidated fiscal position of local governments, prepared each month by the General Treasury of the Kingdom (but not published), are not yet consolidated with statistics for the rest of general government.

- The government finance statistics in GFSY 2003 cover both central government and the social security funds, but not the public administrative establishments. The latest available statistics are for 1999.

The authorities have embarked on an ambitious project aimed at consolidating government finance statistics so that, as of 2005, they cover the whole field of central and local governments.

\footnotetext{
${ }^{4}$ Drawn up by the Ministry of Finance and Privatization's Directorate of the Treasury and External Financing.

${ }^{5}$ Public establishments performing nonmarket activities should be part of general government; the others must be classified in the nongovernment public sector. There is no distinction between EPA and EPIC in Morocco. Law 69-00 on government financial control over public enterprises and other agencies defines public agencies as the government, local authorities, and public establishments and classifies public establishments and enterprises (EEP) in five categories: (1) public establishments (établissements publics); (2) government enterprises (sociétés d'Etat) (enterprises fully owned by government agencies); (3) government subsidiaries (filiales publiques) (in which over half the capital pertains to government agencies); (4) mixed enterprises (sociétés mixtes) (enterprises in which up to half the capital pertains to government agencies); and (5) concessionary companies (entreprises concessionnaires) (enterprises licensed to perform a public service on the basis of a government concession contract).

${ }^{6}$ The 2004 edition of this report rightly classifies the Fonds Hassan II pour le Développement Economique et Social under public administrative establishments, given the nonmarket nature of its activities. When government finance statistics are expanded to public establishments, this Fund will naturally figure in that category.
} 
2. Relations between general government, on the one hand, and public financial institutions and nonfinancial public enterprises, on the other, are transparent and clearly specified. There are no commercial activities in general government and the quasi-fiscal activities of the nongovernment public sector are limited. In general, the government no longer obliges nonmarket public sector agencies-EPIC and public enterprises - to provide noncommercial services not covered by the state budget. In particular, the cost to enterprises caused by price controls on flour and sugar ( 0.7 percent of GDP in 2003) is offset by budget allocations explicitly built into the budget law. Moreover, the legal and financial relations between general government and the rest of the public sector are clearly defined. Government supervision of these agencies is exercised through its participation on their Boards of Directors and by means of the financial and accounting controls contemplated in the November 11, 2003 law, as well as through the growing number of long-term goals and means contracts (contrats d'objectifs et de moyens) between the government and the agencies. Government subsidies for public enterprises and establishments are written into the budget law and listed in detail in the report on public establishments and enterprises attached to the draft budget law and published on the Ministry of Finance website (http://www.finances.gov.ma).

3. Government equity holding in the productive sector is still 1.1.5/2.1.4 substantial, despite the privatizations carried out in recent years. Public sector management is clearly defined. The size of the public establishment and enterprise sector is still significant in Morocco. ${ }^{7}$ The non-financial public sector comes under the Ministry of Finance and Privatization's Directorate of Public Enterprises and Privatization (DEPP), which supervises and exercises financial control over it (Law No. 69-00). Certain public establishments and enterprises are governed by performance contracts (e.g., ONCF [railways], RAM [airline], COMANAV [shipping], ADM [highways], and SUTA [sugar refineries]), which entail reciprocal commitments between the government and the entities concerned. In these cases, financial control is more flexible and referred to as "support."

Relations between the government and nonfinancial public sector and the 1.1 .4 private sector

\section{Public enterprises and establishments engaged in market activities perform a} limited number of quasi-fiscal activities (QFAs). Whenever they are assigned public service mandates, public enterprises are expected to render accounts in their annual reports. A limited number of quasi-fiscal activities subsist and receive financial compensation. For

\footnotetext{
${ }^{7}$ At end-2003, the public establishment and enterprise sector comprised 271 public establishments, 73 government enterprises, 111 government subsidiaries, and 222 mixed enterprises, that is to say, a total of 677 EEP. $^{7}$ As a whole, they accounted for 9.6 percent of GDP in 2003 (compared with 11.9 percent of GDP in 2002 , when the Régie des Tabacs (tobacco company) was still a public corporation) and 23.8 percent of gross fixed capital formation. ${ }^{7}$ Total sales amounted to DH 102.6 billion in 2003 . These figures include those of the 417 public corporation (sociétés anonymes publiques), the 51 public industrial and commercial establishments, and those of the 220 public administrative establishments (the latter units are often smaller and engaged, in principle, in nonmarket activities; yet, their data are aggregated with those of the two first categories).
} 
instance, preferential rates granted by ONCF (railways) to some categories of users are specified in goals and means contracts with relevant public entities and a subsidy offsets the ONCF cost. The QFAs performed by telecommunication enterprises (e.g., expansion of the network to rural areas) are financed by a user fee, administered through a Special Treasury Account.

5. In most cases, the amount of dividends that public enterprises are supposed to transfer to the budget is determined by negotiation between the Ministry of Finance and the agency concerned. Estimates for dividend payments and revenue from monopolies are clearly identified in the budget law.

6. The legal framework for privatization is clear, as is the recording of privatization receipts in the fiscal accounts. The legislative framework applicable to privatizations is defined by Law39-89, which authorizes the transfer of public enterprises to the private sector. The privatization process is administered by the Minister of Finance and Privatization, with the help of a transfer committee; the minimum transfer price is set by an independent evaluation committee. As a rule, invitations to tender are issued; direct transfers by mutual agreement are restricted to specific cases (e.g., when bidding procedures prove inconclusive). The deed of transfer is published. Major privatizations have taken place in recent years, notably in the telecommunication and tobacco sectors (altogether there have been 66 privatizations since the 1989 law).

A substantial portion (up to 50 percent) of privatization receipts is earmarked for the Hassan II Fund (see Box 2). The remainder is recorded as above-the-line (nontax) fiscal revenue.

7. Generally speaking, the laws and regulatory framework governing 1.1 .5 the nonbank private sector are clear and stable, but sometimes complex. A number of different legal and regulatory provisions shape relations between the government and private sector enterprises, above all with respect to procurement, competition safeguards, establishment of new enterprises, investment, ${ }^{8}$ tax law (see paragraph 16), welfare programs, ${ }^{9}$ and labor relations. ${ }^{10}$ Altogether, the institutional and regulatory environment for enterprises

\footnotetext{
${ }^{8}$ The 1988 investment code provides for equal treatment of local and foreign enterprises.

${ }^{9}$ Moroccan private sector wage-earners have a compulsory retirement insurance scheme administered by the National Social Security Fund (CNSS) and based solely on contributions. Optionally, it can be combined with a supplementary pension scheme called the Caisse Interprofessionnelle Marocaine de Retraites (CIMR). Contribution quotas for the basic pension fund are established by decree and the level of benefits defined by law. Contributions to the basic pension system stand at 11.89 percent of gross pay, with a ceiling of DH6,000 a month, one third of which is paid by the employee and two thirds by the employer. The pensions are equivalent to 50 to 70 percent of the average wages of the last eight years of work (with a ceiling of DH6,000 a month) and are distributed after 3,240 days worked. The framework law of April 30, 2003 set a goal of establishing compulsory health insurance and an unemployment benefit as of 2005. These provisions may increase employers' payroll taxes (charges sociales) by 4 percentage points.

${ }^{10}$ Following talks with business representatives, since the end of the 1980s the authorities have made a major effort to clarify and codify these provisions through: the 1998 decree on government procurement procedures;
} 
appears to be relatively clear and stable, despite (1) the complexity of certain regulations (the rules for business corporations; dismissal procedures), and (2) the sometimes lengthy lag between the passing of laws and the issuance of implementing decrees. In addition, there have been recent moves to liberalize some important sectors (e.g., telecommunications, energy, and rail transportation), reflecting increased transparency in relations between the government and the private sector. Furthermore, performance contracts with certain sectors (e.g., fisheries, textiles, tourism) define the mutual commitments of government (in the form of direct support or investment incentives) and its partners to ensure the development of these activities.

8. The central bank (Bank Al-Maghrib-BAM) ${ }^{11}$ is operationally independent and plays a limited fiscal role. A reform of the BAM charter has recently been approved by parliament. This law does not explicitly proclaim the principle of BAM's independence, but does assign it broad operational independence; thus, the Director of the Treasury and External Financing, who is the sole representative of government on the Bank's (nine-member) Board, does not take part in decisions affecting monetary policy. ${ }^{12}$ The bill provides for reducing BAM lending to the Treasury to an interest-bearing overdraft capped at 5 percent of the previous year's tax revenue, for a period not to exceed 120 days. Treasury deposits in BAM do not yield interest and the Treasury pays the same fee for its exchange operations as that paid by financial institutions. BAM's income, net of statutory reserves and optional provisions, and a possible assignment of profits for its personnel, is transferred to the government. In 2002, the Banking Commission exempted three specialized public financial institutions (undergoing restructuring) from the obligation to observe prudential rules for a period of five years. This exemption has saved shareholders, including the government and the CDG, from having to meet, at short notice, the refinancing needs of these institutions, which for the time being remain a possible liability (see below).

9. Public financial institutions perform a limited number of quasi-fiscal activities. Although it has been considerably downsized in recent years, the financial public sector remains substantial: principally, it comprises the head office (caisse centrale) (but not

the law on competition (2001); the law on business corporations (2001); the small and medium-sized enterprise charter (2004); and the labor code (2004). The Labor Code, in particular, which entered into force on June 7, 2004, gathers together in a single document the rules applying to both wage-earners and employers in performing a labor contract (redundancy rules, working hours, minimum wage, collective bargaining, dispute settlement). While the code might appear to be somewhat inflexible, economic agents see one advantage in it: it reduces discretionary powers (particularly those of the courts). The procedures for establishing an enterprise, which used to be lengthy and complicated (it took 13 steps to establish a company), have been simplified following the setting up of one-stop-shop regional investment centers in 2002.

${ }^{11} \mathrm{http}: / / \mathrm{www} \cdot$ bkam.ma/Index.asp

${ }^{12}$ BAM is still represented in the management of, or holds equity in, a number of entities. It is gradually withdrawing from ownership in these institutions, particularly those it oversees, and it is also withdrawing from the management bodies of all the entities in which it is not obliged to participate by law. 
the private local branches) of the leading deposit bank, ${ }^{13}$ two specialized financial institutions, some smaller financial institutions, and the Caisse de Dépôts et de Gestion. Extensive liberalization since the early 1990s has led to the elimination of most quasi-fiscal activities. In particular, most interest subsidies and all obligatory applications of bank funds, as well as all preferential financing windows, have been abolished. However, the following still exist: (1) an obligation for banks to devote 1 percent of their sight deposits to uses that benefit economic and social programs; ${ }^{14}$ and (2) various financing programs for small farmers and low-cost housing, for which the institutions concerned (Crédit Agricole du Maroc and Caisse Centrale de Garantie) receive either budget financing or a government guarantee. ${ }^{15}$ Also, the banks' required reserves earn a below-market ( 0.75 percent) interest rate.

\section{Distribution of fiscal and tax responsibilities within general government}

\section{The fiscal roles of the Executive, the Legislature, and the Judiciary} are clearly defined in the Constitution of September 13, 1996 and in Organic Law 7-98 of November 26, 1998 on the budget law (OL). Public expenditure may be created or distributed only by law, and budget laws (including the budget review law) must be approved by parliament. ${ }^{16}$ Should the budget law not have been passed by December 31 of the current year, the government may by decree appropriate the expenditures needed for public services to operate, based on proposals in the draft budget law. Parliament's powers to amend financial laws are restricted to amendments that do not lead to either diminished government resources or new or greater public expenditure. The Constitutional Council mentioned in the Constitution, and whose powers are established in an organic law, may verify that the budget laws conform to the Constitution and to the OL, if requested to do so by the executive branch or parliament. The Constitution recognizes the existence of the National Audit Office and of the Regional Audit Offices and assigns them responsibility for legal control of public agencies' financial accounts, and seeing that they are managed appropriately. In cases of pressing national need, the government may appropriate additional spending in the course of the year; and it may also defer execution of certain investment outlays in the event of an economic and financial downturn. Responsibility for preparing the budget law is explicitly entrusted to the Minister of Finance on the authority of the Prime Minister.

\footnotetext{
${ }^{13}$ However, 20 percent of the capital has just been sold to the private sector.

${ }^{14}$ The plan is to eliminate this requirement.

${ }^{15}$ Existing legislation does not impose on any agency the obligation to systematically list and publish these QFAs.

${ }^{16}$ Composed of two Chambers: the Chamber of Representatives and the Chamber of Counselors.
} 


\section{Relations between different levels of general government}

11. The distribution of responsibilities among the different levels of government is clearly defined by law but the financial autonomy of local governments is still limited. Administered by elected councils, the regions, préfectures/provinces and municipalities (communes) (see Box 1) are legal entities with their own budgets (approximately 15 percent of the national budget). The powers of the municipalities ${ }^{17}$ cover $^{1}$ above all town and land use planning, sanitation, protection of the environment, and cultural activities; additional powers may also be transferred to them by the government. Local government financing relies largely on tax revenue transfers: 30 percent of VAT revenue for the municipalities and 1 percent of income tax and corporate tax receipts for the regions. The distribution of these resources is based on clear and well received by the local authorities, albeit unpublished, rules. ${ }^{18}$ Local governments also have - albeit on a more limited scaletheir own tax revenue. ${ }^{19}$ The law strictly limits local governments' financial powers, which are subject to legal and financial government supervision ${ }^{20}$ and they may only borrow, subject to government authorization, to finance investment projects.

\section{The legal and administrative framework for fiscal management}

12. Public expenditure management is governed by a clear legal and administrative framework, largely based on the French model's strict separation between officials with power to authorize payment and the public accountants. The rules are very largely observed. Law 7-98 of November 26, 1998 containing the organic law on budget laws clearly establishes the principal rules governing public expenditure management. It upholds above all the principles of universality, unity, and yearly periodicity of budget laws ${ }^{21}$ and provides for independently run government services (SEGMA) and Special Treasury Accounts (CST) which may depart from these rules by earmarking part of their revenue for their expenditure and by carrying forward their end-of-year surpluses to the following years. The law also defines the categories and content of budget laws, the

\footnotetext{
${ }^{17}$ Which constitute the most important category in local finance.

${ }^{18}$ The distribution formulae combine a flat-rate sum per inhabitant, a redistributive portion based on the taxation potential of the local governments, and an incentive component tied to each government's collection effort.

${ }^{19}$ Consisting of local taxes, the rates for which may be established by deliberative assemblies within a range established by the government.

${ }^{20}$ Local government budgets are only enforceable after they have been approved by the Ministry of the Interior (and certified, for its part, by the Ministry of Finance and Privatization-MFP). Their expenditure commitments are subject to ex ante audits by MFP paymasters, who are also responsible for paying expenses and keeping accounting records.

${ }^{21}$ Universality: revenue and expenditures are shown gross, with no possibility of reduction, and all revenue serves to pay for all expenditures, with no earmarking for certain outlays. Unity: all government resources and expenditures are shown in a single document. Yearly periodicity: credits and revenue appropriations are for the fiscal year only.
} 
accounting system for monitoring government revenue and expenditure (modified cash basis, see paragraph 49), the different government revenues and expenditures, and the ways in which budget laws must be presented and adopted. The organic nature of the OL, which precludes even subsequently passed ordinary laws from departing from its provisions, affords a strong guarantee of the stability and continuity of the legal framework governing public finance and, in actual fact, the rules set forth in the OL have always been observed, except in respect of the deadlines for presentation and voting on the budget review law. Moreover, the elimination of annex autonomous budgets, contemplated in the OL, will only be completed in 2005, with the abolition of the RTM annex autonomous budget. Budget execution procedures are, similarly, addressed by a decree dated April 21, 1967, on government accounting, which defines the roles and responsibilities of the various players involved in executing and recording revenue and expenditure operations. It provides, above all, for strict separation between agents responsible for commitment, liquidation, and payment authorization (ordonnateurs) and those responsible for collecting revenue, paying expenses, and handling funds (public accountants or comptables publics). ${ }^{22}$

\section{The mechanisms for coordination and management of budgetary and extrabudgetary activities have not been established with sufficient clarity:}

- The statutes governing the social security systems ${ }^{23}$ and the ways in which the government can exercise oversight over these agencies need to be more precise. The government's contributions to the civil servants' retirement fund, over the period 1957 to June 30, 1996 were limited to the payment to the Moroccan Retirement Fund (Caisse Marocaine de Retraite, CMR) of a subsidy offsetting the institution's annual deficits, which resulted in the accumulation of payments' arrears on the employer's contribution. ${ }^{24}$ However, since July 1, 1996 (i.e., since the reorganization of the CMR), the government paid its employers' contributions in accordance with the laws and regulations in force). ${ }^{25}$ Certain special retirement schemes managed "in house" by some public commercial establishments were recently incorporated in the general pension fund for public establishments known as the Régime Collectif d'Allocations de Retraites ${ }^{26}$ and have therefore become part of general government. However, several other systems undergoing financial difficulties are still excluded from this fund. In general, a significant number of both public and private funds are in a financially delicate situation, above all due to the ageing of the population. These

\footnotetext{
${ }^{22}$ The general regulations governing public accounting is to be revised soon, particularly with a view to including provisions on simplifying and easing the burden of expenditure commitment controls.

${ }^{23}$ Government budget outlays for the social security systems represented 1.2 percent of GDP in 2003.

${ }^{24}$ That is to say, arrears compared to a situation in which the government, as employer, would have paid a contribution consistent with the long-term stability of the system.

${ }^{25}$ The budget appropriation as necessary for the regularization of the arrears due on these contributions has been included in the budget law for 2005 .

${ }^{26}$ Especially the National Railways Office (ONCF) pension fund.
} 
actuarial risks are eventually likely to prompt substantial government budget transfers, in amounts that have not yet been clearly identified.

- Within the national budget, the ways in which special treasury accounts are presented and used are still not sufficiently transparent: information about them in the budget law is scant and the existence of certain accounts appears to justified more by the management facilities provided by these entities than by any objective need to depart from the fundamental rules of fiscal management which are yearly periodicity and non-earmarking of revenue for specific outlays. Nevertheless, the provisions that have created or modified the special treasury accounts describe in an exhaustive way the transactions that can be debited from or credited to these accounts. Furthermore, as regards their management, the transactions on the CST are authorized and executed under the same conditions as the transations of the general budget, except for dispensations mentioned in the budget law and subject to the provisions of Article 20 of the organic budget law. In addition, a report on the CST has been attached to the draft budget law for 2005 to further increase transparency.

- $\quad$ The Hassan II Fund for Economic and Social Development public establishment, which from the time it was established in 2000 (initially as a special treasury account) has been a favorite tool for financing public investment and social programs (see Box 2) has just prepared it first activities report (regarding 2003).

\section{The legislative and regulatory framework for tax policy and tax administration}

14. The legal basis for taxes is clear; tax legislation is modern, but

complicated and subject to frequent amendments. The legal basis for taxes is clear, and the administration's discretion in applying them is limited to presumptive tax mechanisms. The Moroccan tax system was overhauled in the 1980s and 1990s (see Box 3).Its transparency is, however, limited by its complexity (lack of a tax code, multiple exonerations and exemptions, and an abundance of sectoral tax incentives) and by its instability (numerous tax measures aimed at granting tax exemptions for specific activities and products have been adopted since the latter half of the 1990s).

15. There are numerous tax exemptions and an assessment of tax expenditure 1.2.2 is currently being prepared. Numerous tax exemptions are built into legislation (see paragraph 14). They are, however, well defined. In particular, the investment code does not provide for negotiation of the volume of tax or tariff benefits. No assessment currently exists of tax expenditure (only the cost of new measures is estimated). However, the authorities recently decided to install an appropriate evaluation mechanism. This tool should allow decision makers and the public to gauge the fiscal consequences of resorting to tax exemptions.

16. Tax administration procedures are well established. The procedures used $\quad 1.2 .2$ by the Tax Authorities (Direction Générale des Impôts-DGI) are well established in the legislative and regulatory framework. The DGI was recently restructured and, with help from 


\section{Box 3 : The Moroccan Tax System}

1. General income tax. Morocco has adopted a GIT. ${ }^{27}$ The tax base comprises wages and salaries, earned income, farmer' income, real estate income, and capital income. The GIT has five rates, ranging from 0 to 44 percent. For the most part, this tax is withheld at source.

2. Corporate income tax. ${ }^{28}$ CIT is applied to all enterprises, public establishments, and other legal entities. The rate is currently 35 percent. However, financial institutions pay an extra 4.6 percentage points (i.e., 39.6 percent altogether). Taxpayers must pay a minimum quota of 0.5 percent of turnover; its rate is reduced to 0.25 percent for sales of petroleum products, gas, butter, edible oil, sugar, flower, water, and electricity. The contribution can be charged against the CIT.

3. VAT. The $\mathrm{VAT}^{29}$ has five rates: a standard rate of 20 percent, three reduced rates of 14 percent, 10 percent, and 7 percent, and a zero rate. This latter rate, which is normally reserved for exports, is also applied in Morocco to a large number of products for domestic consumption. The multiplicity of rates and exemptions renders the system unstable and undermines the neutrality of the VAT.

4. Domestic consumption taxes (TIC). These excises apply to a limited number of consumer goods (petroleum products, alcohol, sodas, and sugar). Tobacco is now subject to VAT.

5. Import duties. Customs tariffs in Morocco are still complicated with a wide range of rates: eight rates for nonagricultural goods and services (38 rates in all, ranging from 2.5 percent to 50 percent, if agricultural products are included). By decree issued in September 2003, the import duty rate for approximately 4,000 products on the first two product lists ${ }^{30}$ of the Association Agreement with the European Union was lowered to 10 percent.

Representatives of professional associations and private sector economic agents can apply to the consultative committee on imports (CCI) for an "emergency" reduction in the tariffs on inputs. After the government has examined and approved the measure, the initial rate may be changed by a decree, which is presented to parliament for ratification in the next budget law. This is a relatively frequent practice, which heightens the instability of the tax system, encourages rent seeking, and complicates fiscal management.

the IMF, set up a large enterprises facility in Casablance in 2000 and in Rabat in 2001. A single (consolidated) tax identification code, to be shared by the tax and customs authorities and the General Treasury of the Kingdom (TGR) is currently being developed. This code will be the key to constructing a central taxpayer file. The most important measures introduced in recent years to improve tax operations have to do with the adoption of the government claims collection code, the transfer of VAT collection from the TGR to the DGI (in 2004), ${ }^{31}$ the preparation of performance criteria for audits, development of the single identification code, the enhancement of taxpayer information, and delegation of powers with respect to litigation (délégations en matière contentieuse). The DGI has set up a website. More needs to be done, however, to make services more user-friendly and to cater to the needs of small enterprises.

27 see Law 17-89.

${ }^{28}$ see Law 24-86.

${ }^{29}$ see Law 30-85.

${ }^{30}$ Essentially, capital goods, inputs, and consumer goods not produced in Morocco.

${ }^{31}$ This transfer currently applies only to certain categories of taxpayer and to certain towns. All other taxpayers continue to file their returns and pay VAT in the TGR network. 
17. Taxpayers' legal rights are well defined. Taxpayers' rights are well-defined in clearly written laws and regulations. In the event of disagreement between the tax authorities and a taxpayer, both parties are encouraged to reach a settlement. This approach enables most complaints to be resolved. If that is not the case, the matter may be referred to the local taxation committee (CLT) and the National Tax Appeal Committee (CNRF)which must substantiate its decisions to reject an appeal-(administrative phase). These are joint committees. After exhausting administrative remedies, a taxpayer may file an appeal with the courts.

\section{Ethical standards of behavior for public servants}

18. Civil servants are not bound by a specific code of conduct, beyond their duties under the general statute governing the civil service. The civil servants' statute is governed by the Law of February 24, 1958 containing the General Statute of the Civil Service (SGFP), combined with individual regulations for particular categories of public servant (see paragraph 40). Under these statutes, civil servants are obliged to exercise professional discretion (with respect to all information to which they have access in the course of their duties), to respect the state's authority, to act with professional responsibility, and to abstain from conflicts of interest that could impair their independence. Apart from these general principles, there is no explicit code of conduct for public servants. ${ }^{32}$

\section{B. Public Availability of Information}

\section{Coverage and quality of budget documentation}

19. The budget documentation covers all budgetary activities of central

Government - with the exception of the social security systems and miscellaneous agencies of the central government (ODAC) — but the format used to present the breakdown of the budget detracts from its clarity and readability. The presentation of central government budgetary activities is exhaustive and detailed, except until 2004 for the special treasury accounts, for which there had been only a cursory description (see Box 2$){ }^{33}$ The breakdown into four categories of account and the addition of numerous fascicles attached to the budget law make it more difficult to read and understand, while the large aggregates are not easily grasped by uninitiated readers (except in the economic and financial-REF - report). The budget law balance sheet included in the text of the law aggregates both definitive and temporary government operations and it is only in an annex in the REF (which is not approved by members of parliament) that a financial transactions table

\footnotetext{
${ }^{32}$ However, civil servants were recently required to append their signature to a document recalling their obligations under the SGFP and that document was placed in their individual personnel files.

33 See paragraph 13 above for the situation from 2005.
} 


\section{Box 4. Presentation of the Budget Law}

\section{The current budget law distinguishes between four categories of account}

- The general budget ( 85 percent of appropriations) reflects the budgetary operations of the ministry departments. Projected revenues are classified according to the department collecting them and the economic nature of the revenue; administrative appropriations are broken down under two headings (personnel, and miscellaneous material and expenses); and the administrative appropriations are aggregated at the ministry level.

- The SEGMA appropriations (1 percent of the total government budget for 2003) - which make it possible to separate nonmarket activities of government departments (basically, educational institutions and hospitals) from those that are remunerated - form a category of accounts that are separate from the general budget; their revenues and expenditures are shown for each ministry.

- The special Treasury accounts (13 percent of the total government budget for 2003) refer to activities financed by resources especially earmarked for them (the local governments' share of proceeds from the VAT; the food products support fund, the special highway fund) or to temporary government operations (loan and advances accounts); their revenues and expenditure are shown for each individual account, but are not broken down further.

- The annex autonomous budget for Radiotélévision Marocaine (1 percent of appropriations in 2004) is due to be eliminated as of 2005 .

This budget presentation format, which is provided for in the OL, makes the budget law difficult to read but does not lead to distortions in the budget law balance article, which exhaustively lists all the sources of funds and expenses for the budget law's four categories of accounts.

Attached to the budget law are a set of supplementary fascicles

- The introduction to the budget law places it in context and provides analyses of each ministry's draft budget and of specific measures contemplated in the budget law.

- The The economic and financial report provides detailed analyses of the economic and financial situation, as well as a table of central government budgetary operations (excluding extrabudgetary funds and privatization receipts) for the year addressed in the draft budget law, the current year, and the preceding year, using a methodology that approximates to that of GFS 1986, with the exception of privatization receipts which are shown above the line.

- A report on (past and projected) activities of the government services that run independently (SEGMA).

- A report on (past and projected) activities of the public enterprises and establishments.

- The administrative draft budget fascicles (morasses budgétaires de fonctionnement) (each ministry's administrative appropriations broken down by title, chapter, article, paragraph, and line).

- The budgetary employment positions draft budget fascicles (morasses budgétaires d'emplois budgétaires), which detail civil service position by ministry.

- The draft investment budget fascicle, showing the breakdown in one fascicle of the investment appropriations of the ministries, by project and type of expenditure.

- A report on the special treasury accounts (attached to the draft budget law starting with the draft budget law for 2005).

- A statistical annex including in particular data on the macroeconomic framework, on public finances, and on public enterprises and nonmarket nonprofit institutions.

- The synthesis of debates in parliament and responses to the questions raised by parlimentarians and members of the finance committee (in Arabic). 
is shown that uses a methodology that, generally speaking, corresponds to GFS $1986 .^{34}$ Moreover, the presentation of a draft budget for each ministry's operations and a single draft for investment by all ministries makes it harder to form an overall view of each ministry's appropriations.

The budgetary documents do not provide information on either central government units outside the budget (social security entities and non-profit institutions), or on local government. Thus, they do not provide a comprehensive view of general government operations. The authorities have embarked on a project to consolidate the accounts of local governments, which should lead, as of the draft 2006 budget law, to the presentation of projected budgetary activities of local governments.

20. All military expenditure is indicated clearly and exhaustively in the

budget. The administrative appropriations for the national defense authorities are shown in exactly the same way as those for other ministries and are subject to the same audit procedures as other public expenditure items. The detailed budget fascicle for defense has a restricted circulation and is not published.

\section{Final and provisional data in the budget}

21. The budget documentation provides a succinct list of the main fiscal aggregates for the three years prior to the current fiscal year, but does not provide information for the years following the current budget. The economic and financial report attached to the draft budget law (see Box 2) provides aggregate data for the current and two preceding budget outturns (these statements are still provisional when the draft budget law is discussed). These data are broken down into broad aggregates in the projected outturn tables attached to the REF (wage bill, goods and services, and investment expenses) but are addressed more elaborately and in greater detail in the body of the report. So far the draft budget law does not contain forecasts of revenue or appropriations beyond the current fiscal year. ${ }^{35}$ A $2000-04$ economic and social development plan has been drawn up and adopted by parliament. It establishes broad guidelines as well as expenditure projections consistent with a particular macroeconomic framework.

\footnotetext{
${ }^{34}$ The exception is that privatization receipts (excluding those recorded in the Hassan II Fund) appear above the line.

${ }^{35}$ According to the authorities, this situation is rooted in the annual character of the budget law, and is consistent with the first article of the organic budget law which states: "the budget law forecasts, assesses, sets forth, and authorizes, for each budget year, all the revenues and expenditures of the State, within the limit of the economic and financial balance that it defines."
} 


\section{Treatment of extrabudgetary activity}

22. With the exception of the amount involved in external debt guarantees, contingent liabilities are neither listed in the budget documents nor published. In Morocco, contingent liabilities consist of:

- $\quad$ Treasury guarantees for foreign borrowing (at end-2003, these guarantees amounted to 37.3 percent of the total external debt, or US\$5.3 billion, equivalent to 11.0 percent of GDP).

- $\quad$ Treasury guarantees for domestic borrowing, for which records are kept but not published. Today, these guarantees are limited to the low-cost housing sector and a few isolated operations (such as the ONCF debt, contracted when its pension fund was transferred to the RCAR).

- $\quad$ Risks associated with current restructurings, particularly those of certain specialized public financial institutions. The amount of support that the Treasury may eventually have to provide depends partly on the success of the rehabilitation programs under way, especially at the CAM and CIH. The maximum amount involved, according to Treasury estimates, is equivalent to about 1 percent of GDP. ${ }^{36}$

In addition to these contingent liabilities, there are risks associated with the actuarial imbalance in certain pension schemes. Some pension funds (based on distribution), particularly those of (civilian or military) public servants or wage-earners' basic and supplementary pension schemes, are likely to run into financial difficulties in the medium or long term. The pension scheme for public servants and the supplementary pension fund for private sector wage-earners represent a risk equal to 3 percent and 10 percent of GDP, respectively. ${ }^{37}$

\section{The budget documentation contains no tax expenditure estimates,}

but they should be estimated by 2006. Tax legislation, in the form of numerous and complex laws, provides for a plethora of exemptions from ordinary law with respect to direct and indirect taxes, the cost of which in terms of tax expenditure, has not been estimated. A project aimed at evaluating these tax expenditures - no easy task - has just begun and should lead to publication of findings by the time the 2006 draft budget law is presented. (see paragraph 16).

24. As indicated above, in paragraphs 4 and 9, there is only a limited volume of quasi-fiscal activity by financial and nonfinancial institutions. The cost of these activities is essentially recorded in budget expenditures but it is not summarized in the

\footnotetext{
${ }^{36}$ Already, the 2004 budget law includes a DH 200 million item to be used to facilitate the restructuring of the BNDE.

${ }^{37}$ The second risk does not entail an explicit government guarantee.
} 
budget documentation.Nevertheless, Quasi-fiscal activities can be found in the operations of the Caisse de Compensation, whose responsibility is to implement the government policies regarding subsidization of administered prices, including petroleum product prices. The lack of frequency in adjusting retail petroleum prices is the main source of quasi-fiscal activities in this institution, which periodically receives financial support from the budget.

\section{Publication of information on the debt and financial assets}

25. A considerable amount of information is published on the external

and gross domestic debt, but could be expanded. Three annual reports on the public debt are published by the Ministry of Finance and Privatization: (1) A presentation by the Minister of Finance analyzing "Treasury financing and reform of the competitive bidding process;" (2) a report on changes in the domestic debt; and (3) a report on the foreign debt.

- The published statistics on the public external debt show: (1) the stock of the debt (with a breakdown by group of creditors, the composition of the debt by debtor, a breakdown of the debt by currency, and a breakdown by type of interest rate); (2) debt service (principal and interest by broad category of creditors); (3) drawdowns on foreign loans (by the kind of use to which they are put); and (4) major debt management initiatives.

- $\quad$ The statistics published on the government's domestic debt contain detailed information on: (1) the performance and structure of the outstanding debt; (2) the expenses in terms of interest and principal; (3) changes in the net incurrence of liabilities; (4) the projected due dates schedule; and (5) developments in the secondary market.

- Debt statistics are published in the first quarter of the following year. ${ }^{38}$ Debt servicing is performed on the due date.

- $\quad$ The published information is still incomplete. Not published, for instance, are in-year (infraannuelle) data, guarantees provided against the domestic debt, a classification of the debt according to time remaining until maturity, a debt calendar, a concept of total debt including liabilities vis-à-vis BAM and the (in fact, modest) residual stock of domestic payment arrears, debt service projections, and sensitivity analyses.

26. Only part of the central government's financial assets are published.

There are no balance sheet presentations of the (central) government or general government accounts. Only partial data are published: Treasury deposits in BAM, gross international reserves. The stock of Treasury loans and advances is not published. The report on the public establishments and enterprises sector lists government holdings in this sector (by holding threshold), but does not state the value of these assets.

\footnotetext{
${ }^{38}$ There are, however, occasional delays in updating the Ministry's website.
} 


\section{Commitment to timely publication of fiscal information}

27. There is no official commitment to timely dissemination of fiscal data and no advance release date calendars are announced. No law explicitly establishes responsibility for the collection, processing, and dissemination of Government Finance Statistics (GFS). The Kingdom of Morocco plans to join the IMF's Special Data Dissemination Standard (SDDS) by October 2005. The only obligations contemplated in the law are presentation by the government of the draft budget law of the year in question and of the budget review law within the two years following execution of the budget it refers to. The last budget review law passed by parliament referred to the 1998/99 fiscal year, ${ }^{39}$ but a major effort is being made to catch up and stick to legal deadlines: all the budget review laws for 1999-2002 are expected to be passed by end-2005. Highly aggregate provisional data on execution of the government budget can also be found in the economic and financial report attached to the draft budget law (see paragraph 21). Over the course of the year, the MFP's Directorate of Treasury and External Financing prepares a monthly resources and expenditures Table, which is posted on the Ministry of Finance's website, in principle within 20 to 30 days following the end of the month. ${ }^{40}$ This Table is based on provisional monthly accounting statements prepared by the General Treasury of the Kingdom but only disseminated inside the Ministry of Finance. It presents - in aggregate fashion and using a format similar to that of the 1986 GFS - a monthly statement, cumulative since the start of the year, of revenues and expenditures, along with information on the outstanding domestic debt and a breakdown of external debt-related transactions. No information is publicly available on the consolidated fiscal data for the social security systems, with the exception of the data published in the IMF's 2003 GFS Yearbook, for which the latest available data corresponds to 1999. The General Treasury of the Kingdom has begun to prepare consolidated monthly local government accounting statements, but these data only circulate within the government. The only public information on the consolidated finances of the public establishments and enterprises is that shown in the corresponding report attached to the current draft budget law. The Office of the High Commissioner for Planning is required to prepare a consolidated statement of general government finances in connection with the drawing up of the national accounts, but the latest available accounts correspond to 1998 .

\footnotetext{
39 The draft review law for 1999-2000 is being examined by the finance committee of the lower chamber of parliament.

${ }^{40}$ However, the most recent notes were published up to two months following the end of the month concerned.
} 


\section{Open Budget Preparation, Execution, and Reporting}

\section{Budget preparation procedures: clarity and coherence of procedure and presentation}

28. Preparation of the budget, a responsibility assigned to the Minister of Finance, is carried out according to clearly specified procedures that are very well understood and applied by the line ministries. Budget preparation proceeds according to a schedule established by decree, which distinguishes between two essential phases:

- $\quad$ The first, which remains internal to the Ministry of Finance, runs from January to April and leads to the determination of a macroeconomic framework and a comprehensive budget outline (revenue forecasts for the large items, deficit and indebtedness levels, expenditure ceilings, priority sectors).

- $\quad$ The second phase (May-October) is devoted to negotiations with the line ministries, possible arbitration by the Prime Minister, and preparation of the draft budget law documents by the Ministry of Finance (see Box 5). These procedures are shaped by the Prime Minister's establishment very early on (in May) of appropriation ceilings for each ministry that effectively harness and contain the budget requirements submitted by the line ministers. These rules are generally well accepted and applied. ${ }^{41}$

29. Budget classifications comprise economic, functional, and administrative categories and the nomenclature is essentially in line with international standards. The budgetary nomenclature adopted in 1989 for the general and annex autonomous budgets and extended in 1995 to the special Treasury accounts and to revenue, is arranged under (1) three titles (operations, investment, debt), with (2) two chapters per ministry (payroll expenses, and materials and other expenses). Within each chapter, the nomenclature distinguishes between (1) the articles, which indicate the service to be performed or area of investment; (2) the paragraphs, which identify the end use (precise project), or the nature of the revenue; and (3) the lines, which show the nature of the outlay. This juridical nomenclature is completed by functional and economic classifications.

The network of regional governmental Treasurers keeps track of expenditure in the degree of breakdown provided in the draft budget fascicles. Combination of these classifications permits very detailed analysis of operations, provided there is an efficient information system, which should be the case in the framework of the automated data management (GID) project. However, still missing is a localization axis to monitor decentralized expenditures,

\footnotetext{
${ }^{41}$ However, there are sometimes delays with respect to the regulatory deadline (May 1) for sending the budget circulars (notes de cadrage) and certain ministries attempt to elicit from the Prime Minister, at the end of the procedure, supplementary funds above the ministry ceiling set in the instruction briefs.
} 


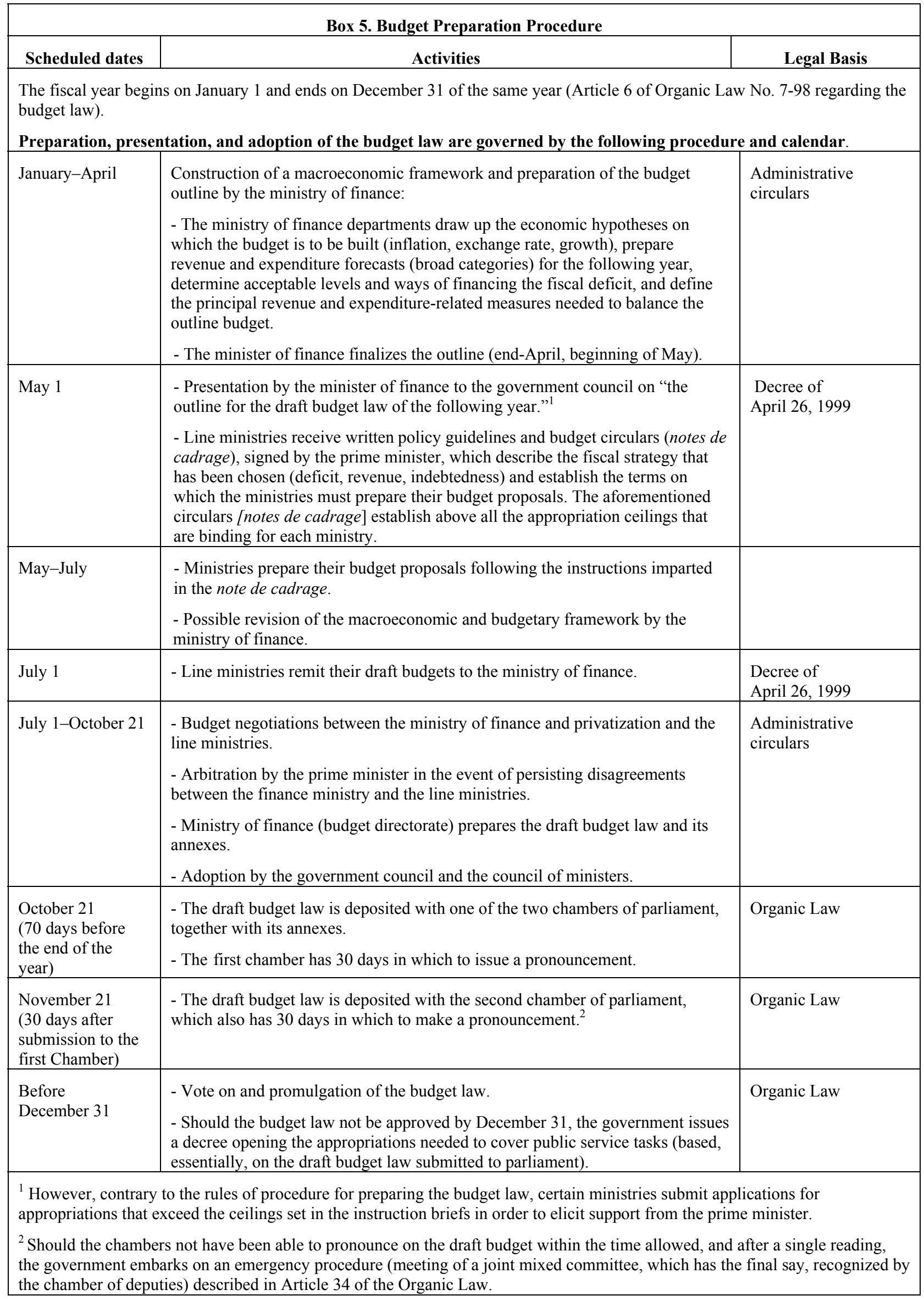


an indispensable tool for keeping track of the decentralization effort. This addition is scheduled to be implemented from 2006.

\section{The macroeconomic framework and the policy basis for the budget}

30. The overall balance of general government operations and that of

the public sector are not monitored. The main indicator of the fiscal position is the overall balance for central government (excluding national public establishments and the social security system, but including privatization receipts). The quantitative magnitude of general government operations not reflected in the fiscal accounts would warrant a more extensive definition of the general fiscal balance. The balancing statement included in the draft budget law shows the balance of general budget operations, of the supplementary budget, the SEGMA, and the CST, but it does not distinguish between final operations and temporary operations (loans and repayments of public debt). This balance is therefore not used for economic analysis of fiscal developments. That analysis focuses on the general balance for the consolidated central government (excluding extrabudgetary funds), as shown in the REF attached to the draft budget law. This balance correctly distinguishes budgetary operations from financing operations, based on a methodology similar to that established in the 1986 GFS. However, the share of privatization receipts that goes to the general budget is considered permanent government revenue and the expenditure component does not include Hassan II Fund operations, which, like the other public administrative establishments, is not included in the consolidated fiscal statistics.

Other budget balances relating to central government operations excluding budgetary funds are estimated by the Directorate of Treasury and External Financing and the MFP's overall economic policy directorate - primary balance, structural balance, balance excluding grants, the primary balance with stabilized medium-term indebtedness - but these are selective, unpublished estimates, which are only used to clarify fiscal options. The overall general government balance is, theoretically, estimated by the Office of the High Commissioner for Planning in the national accounts statistics, but the latest such estimates correspond to 1998.

31. The macroeconomic framework and the assumptions underlying the budget are clearly presented in the economic and financial report attached to the draft budget law. The macroeconomic hypotheses needed to construct the budget are prepared in a well coordinated fashion by the General Economic Policy Directorate (DPEG) and the Directorate of the Treasury and External Financing (DTFE) of the MFP, which also benefit from inputs by the Office of the High Commissioner for Planning. In preparing its projections, the DPEG uses a complex Canadian-designed ${ }^{42}$ dynamic model combined with a simplified framework of accounting relations between the different sectors of the economy. The macroeconomic framework associated with the budget is described precisely and at length in the draft budget law's economic and financial report. That report outlines the main

\footnotetext{
${ }^{42}$ Enhanced by staff of the French Finance Ministry's Economic Forecasts Directorate.
} 
features of the international environment for the fiscal year and then provides detailed projections for domestic economic variables, broken down by economic sectors and components of domestic demand.

32. Independent assessment of the models used to depict the macroeconomic $\quad 4.2 .2$ framework is limited to the technical support provided by the Forecasting Directorate of the French Ministry of Finance under its cooperation arrangement with the DPEG. Apart from that, every year, in the exercise of its statistical functions, the Office of the High Commissioner for Planning prepares and publishes macroeconomic estimates that are independent of those prepared by the MFP. A data series of forecast and actual growth rates, produced in a recent World Bank report, points to a significant improvement in the precision of growth estimates, even though the latter are heavily influenced by agricultural growth forecasts, an area that is in itself subject to the vagaries of the weather.

\section{Medium-term fiscal planning and analysis of fiscal risks}

33. Apart from the general objectives proclaimed in the introductory note attached to the budget, the budget itself is not embedded in a medium-term planning framework and does not assess medium-term fiscal sustainability. The five-year economic and social development plan is not utilized for fiscal planning. The economic and financial report accompanying the budget law contains a general medium-term economic outlook but it is a rough guide rather than a projection based on quantitative analysis of revenue projections and expenditure programs. Spot long-term fiscal sustainability studies are conducted by the DPEG and the Budget Directorate, but are not presented in the draft budget law. The Budget Directorate has, with support from donors and creditors, begun building a medium-term fiscal framework for a three-year period. This 2005-07 MTFF is expected to be published separately from the 2005 draft budget law.

34. Fiscal policy is not guided by preestablished rules. Nevertheless, the government does adopt indicative and nonbinding guidelines regarding the desirable level of deficit ( 3 percent of GDP, including privatization receipts recorded in the budget and excluding extrabudgetary funds), central government indebtedness (65 percent of GDP), and a general (not legally binding) principle of refraining from resorting to monetary financing of the budget. ${ }^{43}$

35. The budget documentation does not distinguish clearly enough between revenue and expenditure estimates corresponding to new initiatives and cost estimates for policies already in place. The draft budget document does not spell out, for the administrative budget (budget de fonctionnement), the reasons for changes (whether increases or reductions) to appropriations vis-à-vis the previous draft budget. In the case of the investment budget, the document sets out the new programs planned for the coming fiscal

\footnotetext{
${ }^{43}$ These principles are stated in the Rapport Economique et Financier (REF).
} 
year. However, for programs already under way there is no clear explanation of payment appropriations, referring these appropriations to already approved projects.

36. The budget does not include assessments of the sensitivity of projections to changes in economic variables and major fiscal risks are not addressed. The budget documentation contains no analysis of the sensitivity of fiscal aggregates to economic assumptions and it does not identify the principal financial hazards, such as those that might arise as a result of the financial plight of public establishments and enterprises.

\section{Clear control over budget execution}

37. Longstanding and effective accounting and internal audit procedures guarantee the correctness of expenditure but would be worth modernizing. The royal decree of April 21, 1967 establishing general rules for public accounting establishes ex ante controls over public expenditure. First, ex ante controls on expenditure commitments ${ }^{44}$ exist for government expenditure, a similar procedure is followed with respect to local governments but less stringent controls exist for non-profit institutions. Then, the public accountants perform an oversight function before they make payments. A notable feature of this system is that it guarantees full knowledge of outstanding payments orders. This longstanding and well tied arrangement is, generally speaking, reliable, even though it is still somewhat formalistic and time-consuming. Some thought has been given to alleviating and streamlining these controls, as well as achieving better coordination among them. Some provisions have already been adopted with respect to audits of expenditure commitments, or public establishments. A December 31, 2001 law $^{45}$ greatly simplifies control of government expenditure commitments by introducing an in-depth audit (un contrôle de substance) based on the risks associated with a particular file, together with a collective stamp of approval and certification for low-value expenditures. It has also introduced a stamp of approval with an observation attached, which has an instructional effect without actually blocking the expenditure unless it is found to be fundamentally incorrect. For public establishments, a November 11, 2003 law provides for some flexibility in the type of audit, distinguishing traditional prior controls from a so-called "supportive" monitoring ("accompagnement"), rather similar to the Government Control exercised in the French system, for establishments with an integrated and reliable management and information system. A single cash flow account is kept for handling central government, regional government, and the public establishments. In the last mentioned category, however, there are numerous exemptions for the commercial sector subgroup, but also for certain administrative establishments.

38. Financial management practices are well coordinated. Overall financial management is handled by the Directorate of the Treasury and External Financing at the Ministry of Finance and Privatization, based above all on information received from

\footnotetext{
${ }^{44}$ Most recently governed by a decree of December 30, 2001.

${ }^{45}$ On the responsibility of those in charge of authorizing payments, auditors, and paymasters.
} 
the General Treasury of the Kingdom. At the start of the year, the Minister issues an initial statement on budget execution. At the end of February, he announces the projected financing requirements for the whole year. Each month, the Treasury Directorate publishes a press release on the financing it intends to raise in the subsequent period. Details of Treasury bill auctions are published every week. With respect to indebtedness, information on the outstanding stock of the debt is provided for broad categories (domestic debt, external debt) in the current economic situation note (note de conjuncture), which is published prior to the end of the following month. For its part, the General Treasury publishes a highly detailed annual domestic public debt account, but with a lag of over six months and only for internal Finance Ministry consumption. ${ }^{46}$

39. Internal audits are effective, but impact assessments and public policy

evaluation still need to be worked on. There are several kinds of internal audit in place. First, the Office of the Inspector-General of Finance (IGF), established in 1960, is charged with conducting ex post audits not only of all payment authorizers and public accountants in the various ministries, but also of all government or quasi-public agencies, including local governments. Currently, the Office of the Inspector has 52 inspectors, whose independence is assured on the one hand by their being directly answerable to the Finance Minister, and, on the other, by the fact that the Inspector General is appointed by Royal Decree (Dahir Royal). The Office of the Inspector verifies correctness and compliance and follows up with a physical (material facts) audit (contrôle de matérialité). A large part of the auditors' reports is devoted to assessing management and performance, as well as making recommendations. ${ }^{47}$ Second, an Audit and Inspection Division in the General Treasury of the Kingdom carries out field audits of the public accountants. Third, several ministries have a general inspector's office responsible for inspecting and auditing departments at the request of the Minister. The reports of these various audit offices are not published outside the government, but some may give rise to disciplinary measures or prosecution, and a few have been commented upon in the media.

Generally speaking, this system provides a satisfactory basis for internal audits. Some progress could be made, however, by continuing to pursue methods based on international standards and by enhancing coordination among the different players. Impact assessments and public policy evaluation also need developing.

40. Procurement rules are clear and well established. A new procurement code $\quad 3.3 .2$ was introduced by decree of December 30, 1998. It aims, above all, to ensure greater transparency, safeguard competition, and raise ethical standards in procurement. Oversight is achieved, before a contract is signed, by the expenditure commitments audit directorate, and prior to payment by the public accountants. Observance of government procurement rules is

\footnotetext{
${ }^{46}$ An annual account for the external debt is currently being prepared.

${ }^{47}$ The IGF is also contractually responsible for auditing government projects financed by foreign grants or loans.
} 
also subject to ex post audits by internal inspectors, the Office of the Inspector General of Finance, and the Audit Office. There is also a Procurement Committee, which performs an advisory function with respect to the laws and regulations, but has no executive powers. Overall, these arrangements meet international standards, although proper implementation of them will require ongoing training and modernization of computerized monitoring tools. In addition, Morocco has a classic conflict resolution system (application for review, judicial appeal, requisition, etc.).

41. Civil service regulations uphold the principle of equal access to government jobs. However, they are complex and insufficiently transparent, and appear to be unsuited to the new needs of government agencies. They are therefore currently being revised. A law dated February 25, 1958 containing the General Statute of the Civil Service (SGFP) ${ }^{48}$ establishes the rights and duties of public servants (see paragraph 19) and proclaims the general principles governing their career (recruitment, remuneration, promotion, grades, mobility, leave, disciplinary sanctions, and separation from service). These rules include equality of access to government employment, a prohibition on performing private activities for profit, protection of civil servants from attacks on their person, intervention of a disciplinary council in cases involving serious violations, publication of appointments and promotions in the official bulletin, and provisions for exonerating civil servants from civil liability for mistakes made in the course of duty. Apart from these principles, the SGFP refers to over 50 individual statutes establishing by decree the exact rules applicable to each category of public servant. These rules are not well harmonized so that application of the current regulations can lead to different treatment of officials with comparable duties. Moreover, the very general nature of the SGFP provisions leaves a wide margin of interpretation, which has been extensively exploited in the regulations contained in the individual statutes. For instance, Article 22 of the SGFP only asserts the principle of competitive recruitment "subject to the temporary provisions contemplated by law" and, in fact, only certain categories of public servants are recruited through competition, while others are selected on the basis of qualifications or just interviews. Furthermore, current rules, which are essentially based on promotion through seniority, do not allow merit awards, or recruitment of persons whose profile best suits the needs of the administration, or geographical or functional redeployment based on needs. The authorities are aware of these drawbacks and, with the support of donors and creditors, have embarked on a major reform of the General Statute aimed, above all, at establishing competitive recruitment as a universal norm, developing an incentive-based remuneration system, encouraging mobility among public servants, and harmonizing the different statutes in effect today.

\footnotetext{
${ }^{48}$ Amended 10 times between 1958 and 2001.
} 


\section{Clarity of internal audit procedures and independence of the tax authorities}

42. The tax authorities follow strict internal audit procedures. The tax

authorities' replies to taxpayers' questions are published and may be used against it. Computerization of tax administration is currently the subject of a reform in which new computer programs are being installed at both the DGI and the TGR. An internal audit department exists.

43. Tax administration staff have the same legal protection prerogatives as those offered to other public servants. The General Directorate of Taxes is a directorate within the MFP. Its Director is appointed by decree (Dahir). The staff's rights are established in the civil service statute.

44. The accounting system supports preparation of thorough and generally 3.3 .1 accurate reports over the course of the year on central government budget execution. The general accounts of the central government and regional governments are kept by a network of government accountants, whose work is then centralized by the General Treasury of the Kingdom.

In the case of government operations, the General Treasury compiles:

- $\quad$ Every day, a set of performance indicators for the Minister, along with certain data; Treasury cash assets, payments pending, outstanding amount of Treasury bills.

- $\quad$ Every month, approximately D+30, a Treasury operations statement, showing the accumulated total for broad headings and balances and comparing outturn with budget forecasts and the previous year's outturn. This document is distributed within the Ministry of Finance and addressed in particular to the DTFE for the purpose of drawing up the monthly statement of Treasury expenditures and resources.

- $\quad$ At the end of the year, the General Treasury draws up the overall fiscal account, which fully consolidates the operations carried out during the year. This document is referred for audit to the Audit Office and then becomes a major component of the budget review law. At the present time, this account is drawn up with a considerable lag: at June 30, 2004, the most recently drawn up account was for 1999-2000.

Accounting data are consistent with fiscal accounting, thanks to a subsidiary accounting system, which records operations with the same level of detail as the budget law.

Furthermore, the accounting system makes it possible to ascertain payment arrears at any time.

45. While, generally speaking, the accounting system yields timely and reliable information on government budget execution, it does not provide such timely information for the local public sector nor the cumulative central government-local government position. A consolidated account for 2003 operations should be available 
shortly, and be followed by regular monthly statements. At the same time, with respect to central government accounts, monthly statements are not yet totally exhaustive.

46. The government's chart of accounts is very old and no longer meets either national or international standards: it does not support monitoring of the accrual basis type, or presentation of a full-fledged statement of government operations and balance sheet. A draft of a new chart of accounts has been prepared. In 2001, it won the approval of the National Accounting Council (CNC), but it will not be applicable until, at best, January 1, 2006. At the same time, a draft chart of accounts for local governments is currently being examined by the $\mathrm{CNC}$.

47. Fiscal reporting covers central government but not the whole of

general government. Only central government operations can be shown in in-year accounting statements, which cover operations of the General Budget, the Annex Autonomous Budget, the Special Treasury Accounts, and the independently run government services. Apart from them, and given the current state of information systems, only local government operations can be consolidated with those of central government. The consolidated account for central and local government operations and their communities for fiscal year 2003 was drawn up tentatively and presented in July 2004. The operations of the public establishments, which are not carried out by accountants belonging to the General Treasury network, are not consolidated, even on a yearly basis. The only aggregates drawn up - by the Directorate of Public Enterprises - are taken from a sample of the largest entities.

\section{Parliament is informed at midyear of the fiscal situation; it receives}

information on the fiscal situation for the current year in a statement made by the Minister of Finance and Privatization before the Finance Committee. The government also answers specific questions posed by parliamentarians in the course of the year on execution of the budget law. In addition, sessions are organized for presentations on specific topics, such as fiscal reform, the status and possibilities for reform of the pension system, and the remuneration system for public servants.

49. Audited final accounts are not available within $\mathbf{1 2}$ months of the end of

the fiscal year. Although the Organic Law on the budget law provides for the budget review law being voted on by parliament before the end of the second year following the end of the fiscal year, until a few months ago, lags of several years were observed. The departments involved have taken steps to catch up: the idea is to present the budget review law for 2002 to parliament by the end of 2004. The final accounts published in the budget review law are published in the official bulletin and on the Ministry of Finance's website. These accounts record all the government operations contemplated in the budget law and thus include those of the decentralized departments. The operations of local governments and public establishments do not appear there, inasmuch as the budget review law is supposed to ascertain the final amount for revenue collections and disbursement orders under the central government budget. 
Drawing up the budget and monitoring its execution by comparison with the objectives set

50. Overall policy objectives are announced, and actual progress

made toward achieving them is communicated to parliament; on the other hand, budgeting and monitoring are still based on input line item budget principles. Overall objectives are presented to parliament in connection with the economic and financial report that accompanies the budget law; in the 2004 budget law, there were some 15 objectives. However, only those objectives that directly affect the major macroeconomic stability objectives are accompanied by quantitative indicators. There is not yet any systematic communication of goals and results to the general public. Both budget formulation and monitoring are still conducted in accordance with input line item budget principles. With respect to objectives assigned to "deconcentrated" government bodies, the practice is in the process of being introduced as local administrators take on new responsibilities and in response to the globalization of appropriations. In 2004, five ministries, accounting for 17 percent of investment appropriations, are conducting an experiment with globalized appropriations.

\section{Assurances of Integrity}

\section{Integrity in the processing of data}

51. The fiscal data are generally reliable and the discrepancy between 4.1.1 forecasts for the principal fiscal aggregates and actual results is shown and explained to parliament, but not to the public. The rates for actual use of budget appropriations, judging by the tables shown in a World Bank fiscal management evaluation study conducted in October 2003, testify to considerable accuracy in the forecasts: often over 95 percent in the case of administrative operations and similar rates for investment commitments. Exceptional appropriations remain at a reasonable level: in 2004, the volume of appropriations for unforeseen expenses is largely made up of provisions for increases in wages and allowances for early retirement (DH 2.3 billion). These different discrepancies are analyzed and explained to parliament, especially in the economic and financial report accompanying the budget law. Shifts in appropriations in the course of the year-which are still relatively modest - are carried out by decrees that are not published but which are submitted for examination by the Audit Office in the framework of the budget review law. However, revenue projections presented in the annual budget are generally conservative and revenues actually collected are in general higher than the budget estimates.

52. No statements are made about the accounting basis in the budget documentation or final account documents. The accounting follows "modified cash basis" procedures: expenditures are recorded when payment orders are approved, and revenue is recorded when they are collected. The double-entry bookkeeping system is used, which allows monitoring of temporary or pending operations. While these rules, derived from the 1967 decree on government accounting, are still generally reliable, they no longer conform to international standards. The draft Chart of Accounts about to be decreed for 
application in 2006 meets national standards and is consistent with international standards. However, if it were to be postponed until a later date, it would be worth reviewing certain aspects to take into account recent development in accounting information systems.

\section{The procedure for reconciling the accounts and fiscal data is effective}

enough, but very cumbersome. Reconciliations between accounting reports and budget appropriations are conducted on a regular basis at several levels and are clearly shown in the general fiscal account (compte général de l'administration). Overall, these mechanisms are reliable, but also cumbersome, time-consuming, and expensive. Commitment-basis accounting is carried out by payment authorizers and expenditure commitment auditors, who adjust to one another in quasi real time. Reconciliations are subsequently carried out, at least once a month, between the payment authorizers' fiscal accounting and the general accounting ledgers kept by the accountants. However, these adjustments are made more difficult in the course of the year by persistent time-lags in taking the carrying - over of appropriations into account, which partly explains the time needed to draw up the general fiscal account and, hence, to prepare the budget review law. At the Ministry of Finance and Privatization, there is an Integrated Expenditure Management project (GID) that aims to provide all players with a shared information system, which should insure that the various monitoring efforts are in line with one another and expedite the production of periodic statements and final accounts. Reconciliations between the Treasury's accountants and BAM take place every day at the individual item level and once a month at the central level. Regular reconciliations are also conducted with the Postal Current Accounts department. Consistency tests for indebtedness and the budget deficit are possible, using the General Treasury's accounting and data held by the Directorate of the Treasury, which authorizes movements in the debt accounts. The establishment at some future date of accrual-basis accounting should facilitate this exercise.

\section{Independent scrutiny}

54. The external audit is independent of the Executive Branch and covers the 4.2.1 entire field of general government. The independence of the Audit Office is guaranteed by the Constitution promulgated on October 7, 1996. A law of June 13, 2002 on the Financial Courts Code establishes the ways in which the Audit Office and the Regional Audit Offices perform their missions. The First President and the Royal Prosecutor are appointed by Royal Decree (Dahir). All the judges are appointed for life. The budget for the Audit Office and the Regional Audit Offices is established by parliamentary vote.

In principle, the First President submits an annual report to the King. The financial courts perform the following audits:

- A comprehensive management audit of government departments, local governments, and agencies in which government agencies have a majority share. 
- $\quad$ An audit of the use of public funds administered by subsidized agencies.

- $\quad$ An audit of funds collected by appeals to the public's generosity.

In addition, the audit office issues a report on budget law execution, containing a general statement to the effect that the individual accounts presented by the accountants match the general fiscal account of the Kingdom, is presented to parliament in support of each draft budget review law. Parliament may ask the president of the audit office for further explanations of the contents of its report.

The audit office began its work in 2003, based on the new law, but first must attempt to catch up with the backlog of audits of the public accountants' accounts. At the same time, it is involved, like the other players, in the goal of expediting presentation of the draft budget review law, since it is its responsibility to give prior approval to the general fiscal account.

55. Audit capacity needs to be strengthened. A far-reaching restructuring is 4.2.1 underway, ever since the Financial Courts Code entered into force in 2003. Nine regional courts (Audit Offices) have been installed and the (national) Audit Office has been reorganized into five divisions. Various steps have been taken or are contemplated to boost the capacity of the courts over the medium term, especially with respect to methodologies, the recruitment of new judges and training, and information technology. These arrangements appear destined to ensure that the courts operate effectively, provided that the program embarked upon is diligently pursued in the coming years and adequate budgetary resources continue to be forthcoming.

56. There is no systematic external assessment of the macroeconomic models $\quad 4.2 .2$ and assumptions underlying the budget law. The macroeconomic forecasts are still made by government departments and are not debated in a committee or by an independent body. ${ }^{49}$

57. The Statistics Directorate of the Office of the High Commissioner for

Planning enjoys extensive de facto independence. Despite the absence of legal provisions to ensure the independence of the Directorate of Statistics and National Accounting (the Moroccan statistics agency), this administrative department enjoys distinct operational independence, which has been further strengthened by the transformation of the former Ministry of Economic Forecasting and Planning, which it comes under, into the Office of the High Commissioner for Planning.

\footnotetext{
${ }^{49}$ As indicated above, the macroeconomic models were originally constructed with external assistance and evaluation.
} 


\section{IMF STAFF COMMENTS}

58. Morocco's fiscal management system, which remains centralized and

focused on strict controls to ensure that expenditure items are correct, is essentially reliable and supported by legal safeguards and is adequate for steering budget performance. The far-reaching amendment of the organic law governing budget laws carried out in November 1998, the legislative and regulatory provisions that accompanied it, and the recent reforms have led to significant progress with respect to the clarity of fiscal and accounting standards, access to financial reporting, the quality of financial data, and control over the processes involved in preparing and executing expenditure.

59. The degree of fiscal transparency today is, generally speaking, satisfactory:

- Management of government revenues and expenditure now takes place within a precise regulatory framework offering strong guarantees of stability and legal security to those involved and assigning to the different players in central government clear and precisely defined responsibilities. In particular, the structure and functions of central government are clearly specified, and the division of powers between the Executive and Legislative Branches in fiscal matters is well established. The relations between government and the other public sector agencies have partially been clarified, as a result of the increasingly watertight separation between the fiscal activities of the government and the monetary responsibilities of the central bank. Government intervention in the private sector, which is still substantial despite a recent surge in privatizations, is both open and public and guided by transparent rules.

- The access of parliament and public opinion to financial and fiscal information is broadly satisfactory, and the government is committed to ensuring ample dissemination of the data related to fiscal management. Budget preparation, which is characterized by control over total appropriations very early on in the process, proceeds according to clearly defined and well understood processes. The macroeconomic framework underpinning the budget is exhaustive and homogeneous and its underlying assumptions are clearly described and published. The budget presentation documents provide relatively detailed information on fiscal aggregates, even though it is dispersed, complex, and insufficiently standardized.

- $\quad$ Expenditure execution procedures are reliable and clearly organized and 3.3 support effective control over expenditure authorizations granted by parliament. Ex ante audit systems for expenditures make it possible to prevent irregularities and obtain highly reliable execution data, even if these procedures are slow and formalistic. The Constitution recently recognized the existence of an independent, external control body (the Audit Office), whose role still needs strengthening in order to ensure effective auditing of government agency accounts and to initiate a true management audit of the officials responsible for authorizing payments. The Statistics Directorate of the Office of the High Commissioner for Planning, which constitutes a 
ministerial department, enjoys extensive de facto independence in going about its work.

60. Progress is still needed, however, if Morocco's public finances are to become as transparent as international standards require.

- Government budget coverage and the scope for applying public expenditure management procedures are restricted to the operations of central government agencies, leaving out the mandatory social security systems, non-profit institutions (of which the Hassan II Fund) and local governments. The increasing importance of the government activities other than those of central government departments and the wide range of risks associated with them-above all in the financial sector and with respect to the actuarial stability of pension schemesrequire that the boundaries of the government budget coverage are gradually pushed back so as to include all general government. In particular, the nature of the Hassan II Fund operations would require that its operations be included in the central government's fiscal table, which is presented in the economic and financial report annexed to the annual budget law. In the longer term, fiscal reporting and monitoring should be expanded to the whole central government (including its extrabudgetary units such as social security and nonmarket nonprofit institutions), and broadened to cover local government as well. At the same time, the quality of fiscal data could be improved by (1) disclosing the sources and methods underpinning the preparation of fiscal data; (2) providing information on historical series of monthly fiscal statistics; and (3) issuing a publication schedule for the issuance of fiscal information. longer meets the administration's needs. It needs to be revamped as soon as possible, so that additional information can be made available on the tracking of the use of appropriations through clear and exhaustive accounting statements. To that end, the TGR has prepared a new government chart of accounts, which has been adopted by the CNC.

- $\quad$ The lack of a medium-term fiscal framework (MTFF) and the summary nature of the information published in the budget law for the years preceding the fiscal year do not permit an assessment of the fiscal choices for the year as a function of past outturns and medium-term fiscal constraints. The establishment of a MTFF closely coordinated with preparation of the annual budget law would make it easier to assess short- and medium-term fiscal sustainability and would facilitate the execution of any savings programs ${ }^{50}$ that might prove necessary in order to ensure the budget's sustainability.

\footnotetext{
${ }^{50}$ Particularly with respect to the wage bill.
} 
- $\quad$ The risks associated with fiscal management in connection with contingent

liabilities and the actuarial stability of pension schemes are not systematically assessed, and the budget law contains no exact information on these matters. The large volume of operations undergoing financial restructuring and the fragility of several major pension schemes mean that more homogeneous and detailed information on these matters needs to be given to parliament and to public opinion.

- $\quad$ Parliament is insufficiently informed of the conditions governing budget 3.4 Law execution due to delays in the presentation of budget review laws, ${ }^{51}$ disaffection due to the budget law correction procedure, and the lack of systematic fiscal information at midyear. ${ }^{52}$ The dispersion of information in the draft budget law also detracts from the readability and accessibility of the budget documents, whose format needs to be simplified. The information contained in the budget law - although it is already dense and detailed - could be further improved. Currently, there is no summary statement on the level of tax expenditure; the information on the Special Treasury Accounts is insufficient; and the important role of the Hassan II Fund in financing public investment would warrant more information being supplied about its activities.

- Management of public expenditure is still shaped by a rationale of inputs and fraught with cumbersome and complicated pre-audit procedures, which leave too little room for manager accountability. Fiscal choices are sometimes made without sufficient heed to the objectives and outcomes of government action, even though there have been some recent initiatives aimed at introducing performance-oriented budgeting. These initiatives would need to be gradually expanded once the new fiscal and accounting framework created by the reforms at the end of the 1990s has become stabilized. ${ }^{53}$

- The proposals put forward along these lines are ranked according to decreasing order of priority. A significant number of these proposals have already been examined by the authorities and several of these recommendations are at the project stage or even in some cases (study group assessing tax expenditure, preparation of a report on the CST, preparation of a MTFF) have already begun to be implemented.

\footnotetext{
${ }^{51}$ The budget review law for fiscal year 1998-99 is only now being passed by parliament. For the fiscal years thereafter, the ministries concerned have been pressed into submitting the corresponding review laws to parliament before the end of 2004.

${ }^{52}$ Although there is no official and systematic report by the government to parliament on execution at midyear, the Ministry of Finance and Privatization does provide outturn information to the parliamentary finance committees. Summary information is provided on budget law execution for years n-2 and n-1 when the draft budget law for year $\mathrm{n}$ is being examined. Members of parliament may also question the MFP on budget law execution by means of oral and written questions.

${ }^{53}$ The TGR is studying the possibility of audit reforms aimed at making them less cumbersome and more selective.
} 
A. Expand the coverage of fiscal statistics and introduce the notion of expanded overall balance as an essential criterion for assessing fiscal strategy:

- $\quad$ Gradually expand the scope of application of fiscal policy and fiscal management procedures to the whole of general government.

- $\quad$ Begin by ensuring complete coverage of central government by making sure that there is regular monitoring of the consolidated fiscal position (in its current form), with the addition of the Hassan II Fund and then of the other non-market non-profit institutions and the mandatory social security systems.

- $\quad$ Recognize the overall balance of central government fiscal operations (including social security agencies and nonmarket establishments) as a fundamental indicator for tracking fiscal developments. Initially, monitor the balance of the consolidated fiscal position and an expanded balance that includes all the nonmarket agencies for which information is available (including the Hassan II Fund).

- $\quad$ Then extend this boundary to include local governments.

- Eventually introduce indicators for monitoring the whole of the public sector. ${ }^{54}$

B. Modernize the general accounting system for central government and local government operations, in addition to fiscal monitoring of the use of appropriations:

- Undertake within two years a reform of the government chart of accounts, to make it comply with national accounting standards and be consistent with international standards, while at the same time ensuring full consistency between the subsidiary fiscal nomenclature for expenditure and the government chart of accounts.

- Implement the new chart of accounts for local governments.

- $\quad$ Add expenditure localization criteria to the government's fiscal nomenclature in order to enable development of fiscal decentralization.

- $\quad$ Expedite implementation of the integrated expenditure management system (GID).

C. Draw up the budget in the basis of a medium-term framework:

- $\quad$ Complete preparation of the medium-term fiscal framework.

\footnotetext{
${ }^{54}$ These recommendations presuppose that a general government account is drawn up year after year by the national accountants at the Office of the High Commissioner for Planning on the basis of accounting data (and not estimates) and hence that the necessary statistical and accounting information are made available to it in an effective and timely fashion and with an appropriate amount of detail.
} 
- $\quad$ Use the first year of the MTFF as the point of departure for preparing the annual budget.

D. Simplify the presentation of budget documents so as to make them more accessible and readable:

- $\quad$ Reduce the dispersion of annual budget accounts by expediting moves to get rid of the SEGMA and of the CST whose existence is not justified, and by avoiding the establishment of new similar entities.

- $\quad$ Improve the presentation of the balance statement (tableau d'équilibre) voted on in the budget law by distinguishing between final and temporary operations.

- $\quad$ Consolidate, in a single fascicle per ministry, the administrative and investment $\quad 3.2 .1$ appropriations corresponding to that ministry.

- $\quad$ Separate general government from the public sector in the report on public enterprises and establishments attached to the draft budget law.

- Introduce the custom of making a general fiscal policy statement before parliament prior to presentation of the draft budget law.

E. Strengthen risk assessment and management in the area of government 3.1 .5 finance:

- $\quad$ Undertake a systematic evaluation of the actuarial risk posed by mandatory social security systems and publish that information along with the budget documentation.

- $\quad$ Publish in the same manner an annual analysis of contingent liabilities.

- Include in the budget an analysis of the sensitivity of fiscal estimates to changes in economic variables and a study of medium-term fiscal sustainability.

- Strengthen government control in public enterprises and establishments posing the highest potential risks to fiscal stability.

F Improve the information given to parliament and to the public on the conditions surrounding execution of the budget law:

- $\quad$ Observe legal deadlines with respect to presenting and voting on the budget $\quad 3.4 .2$ review law.

- $\quad$ Present a midyear report to parliament on the conditions surrounding 3.4.1 execution of the current budget law. 
- $\quad$ Announce a release date calendar for publication of the Treasury's general statement of revenues and expenditures and increase the degree of detail shown in these tables.

- $\quad$ Revise the practice of amended budget law and, as a corollary, reduce the volume of non-specific appropriations in the budget law (allowance for unforeseen expenses and common costs).

- $\quad$ Publish an annual general government and public sector account in support of the budget review law.

- $\quad$ Communicate to parliament the annual report of the expenditure commitments $\quad 3.4 .2$ audit.

- $\quad$ Publish the regulations governing the transfer of appropriations.

\section{G. Enrich the information presented in the budget documentation:}

- $\quad$ Present an annual fiscal expenditure statement.

- Improve the information available on the Hassan II Fund by devoting a special report, to be attached to the draft budget law.

- $\quad$ Grant certain documents attached to the budget law the status of mandatory attachment: the REF, individual ministry budget fascicle, reports on decentralized government departments.

- $\quad$ Distinguish, in the presentation of appropriations, between new measures (increases or decreases in the appropriations) from appropriations needed to continue already established policies.

\section{H. Undertake efforts to codify fiscal laws and regulations:}

- $\quad$ Bearing in mind the range of risks that the government budget may have to support, clarify the respective roles of central government, the social security funds, and the representatives of the insured party in preserving the long-term financial stability of social programs and governmental control/supervision of these programs.

- $\quad$ Introduce criteria for legally distinguishing between the EPA and the EPIC. governments (General Code for Local Governments) and the civil service (General Statute of the Civil Service). 
- $\quad$ Establish the universal principle of civil service recruitment through

competition.

- $\quad$ Publish the laws and regulations regarding the ways in which taxation transferred to local governments is distributed.

I. Gradually implement performance-oriented fiscal management and 3.4 .3 encourage evaluation practices in ministerial departments:

- $\quad$ Put in place a classification of missions and programs associate with precise governmental goals.

- $\quad$ Prepare a limited number of pertinent performance indicators for each of the programs.

- Increase the fungibility of appropriations within programs.

- $\quad$ Establish general procedures for contracting between the central government, its EPIC, and public enterprises.

J. Gradually ease the burden of formal priori controls (based on the reliability of the management procedures of the entities concerned) and replace them with a systematic and revamped ex post audit.

- $\quad$ Make the supportive financial audits general procedure in the more efficient $\quad 3.3 .3$ EPA and EPIC.

- $\quad$ Continue fiscal monitoring of the financial courts to ensure that they comply $\quad 4.2 .1$ effectively with their jurisdictional and management audit mandates.

- Install management audit units in the ministries' financial directorates. $\quad 3.3 .3$ 


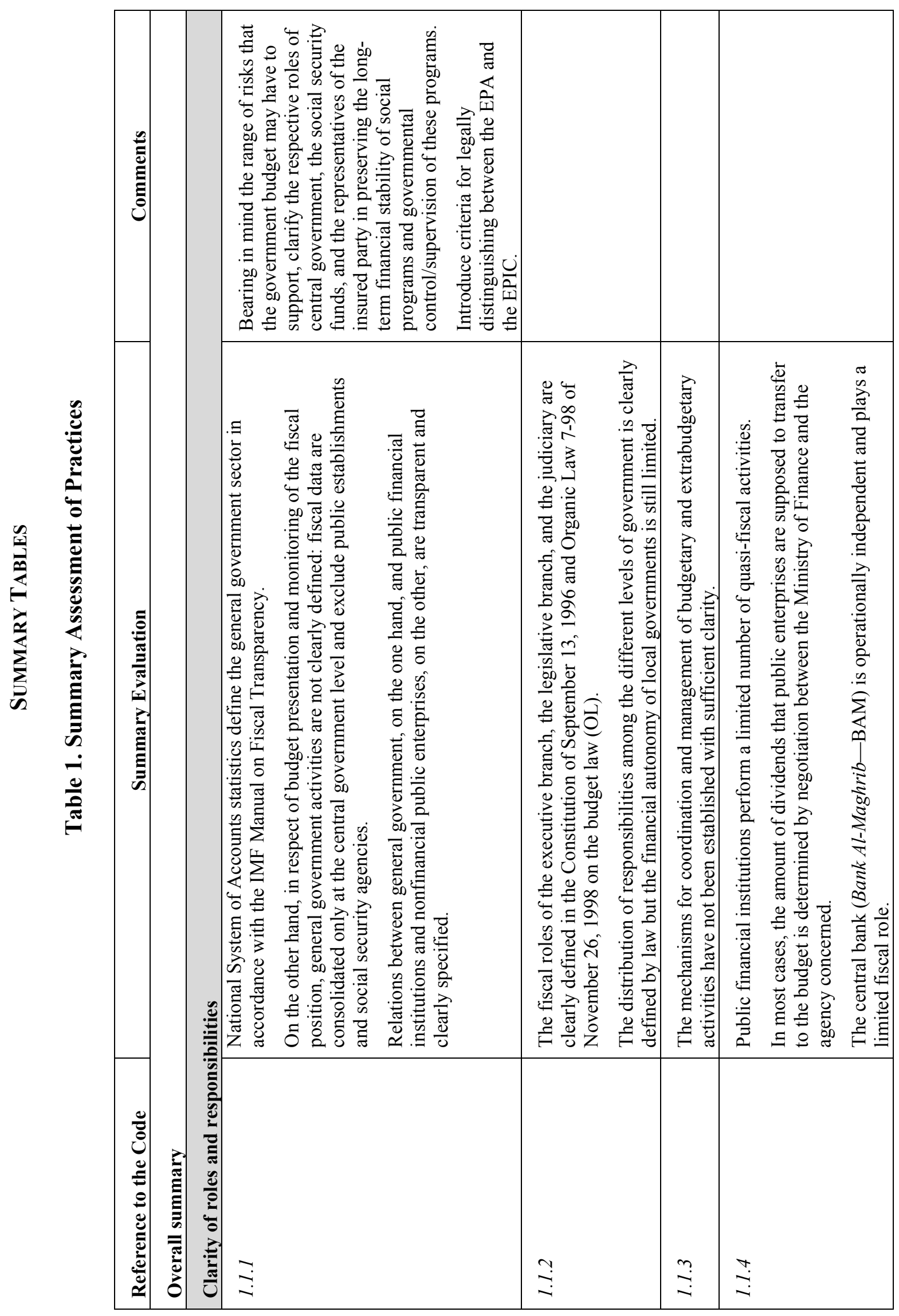




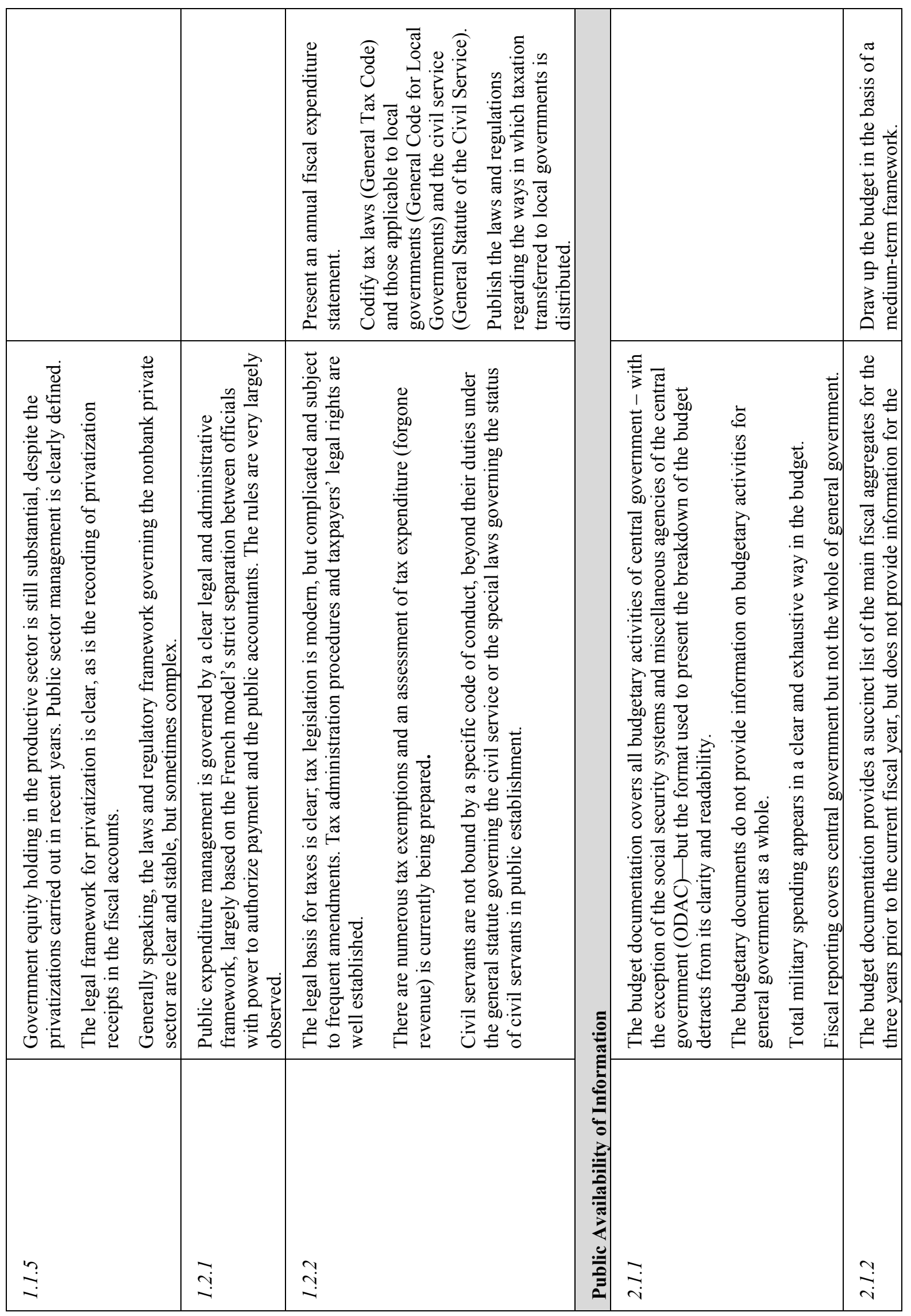




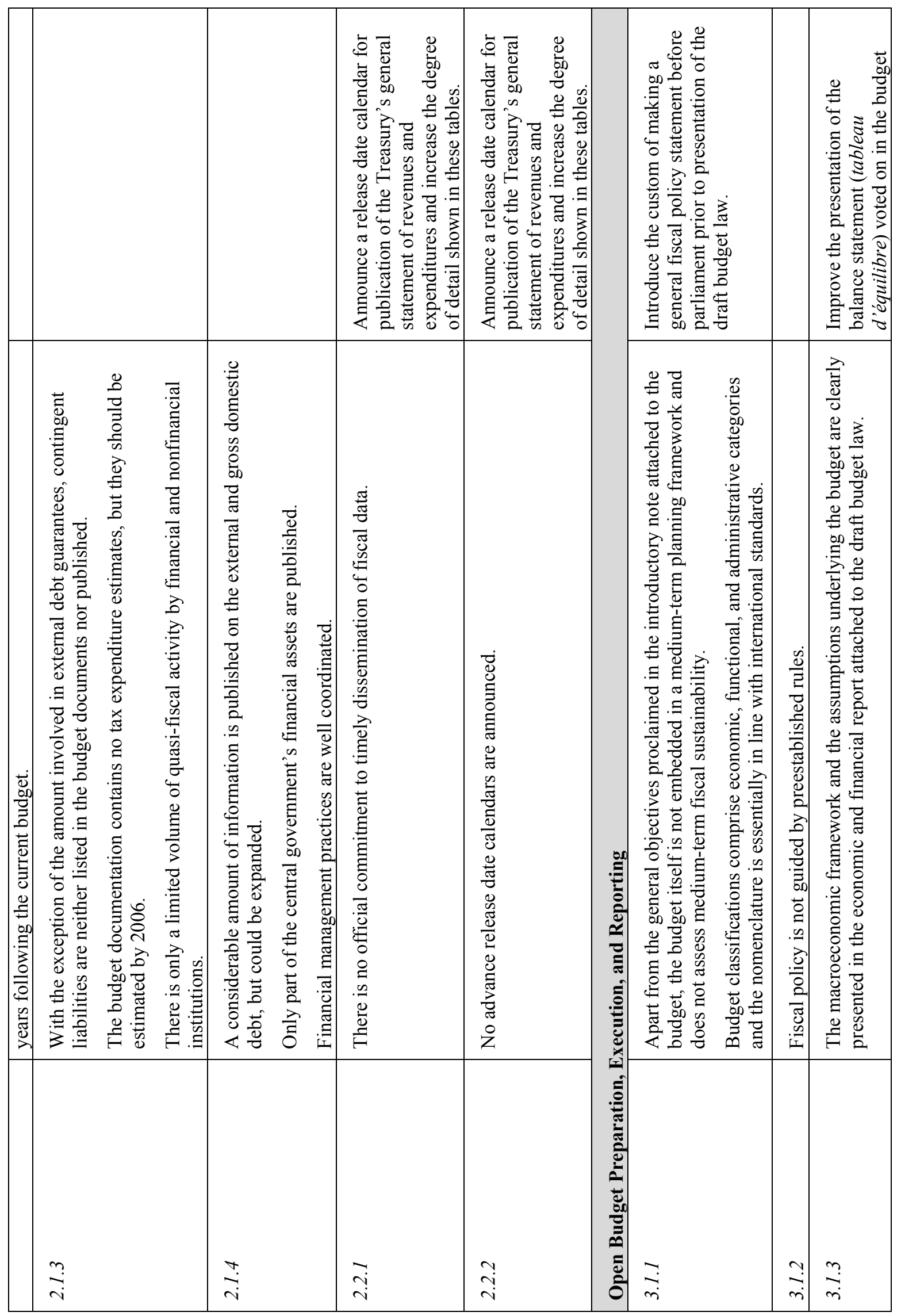




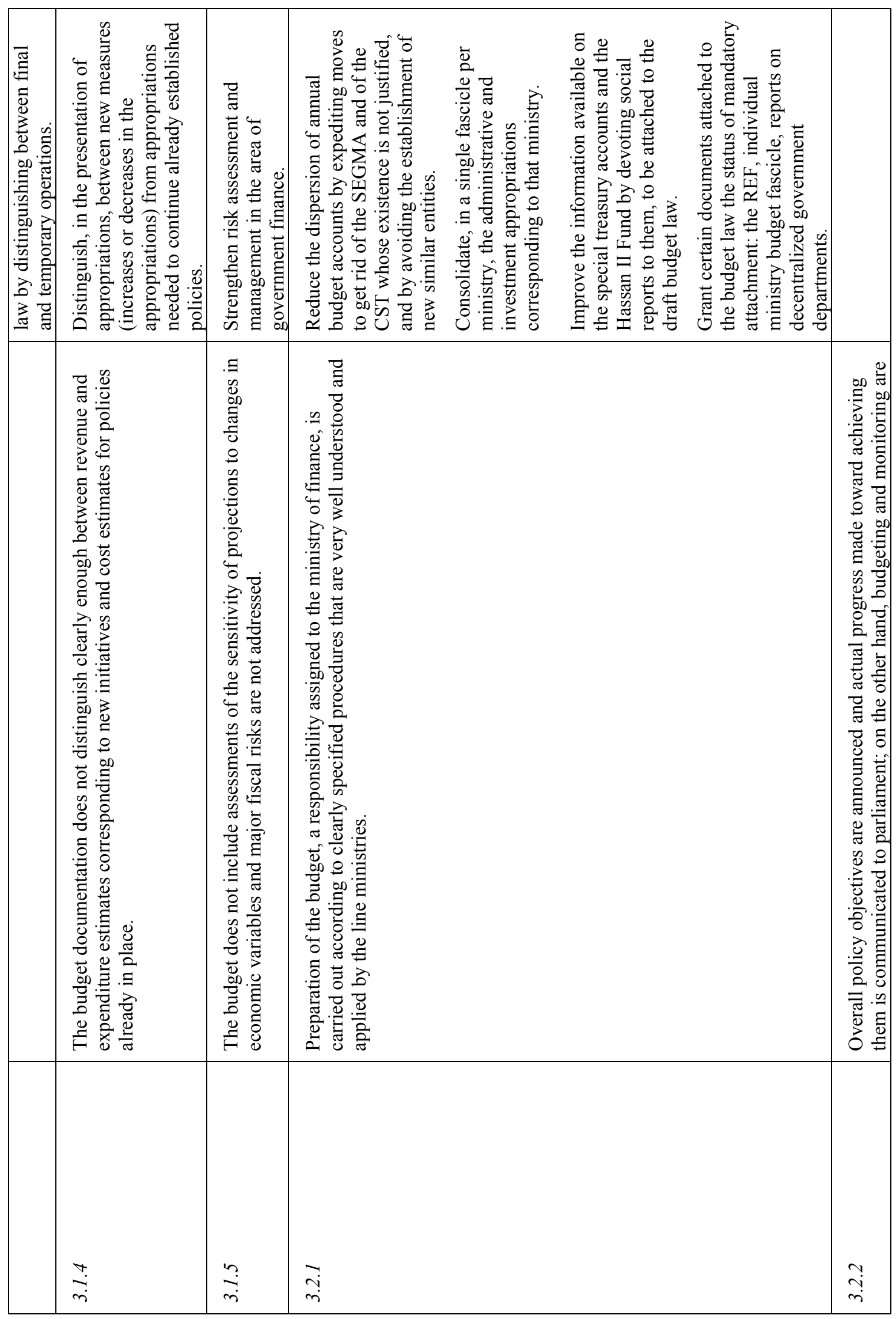




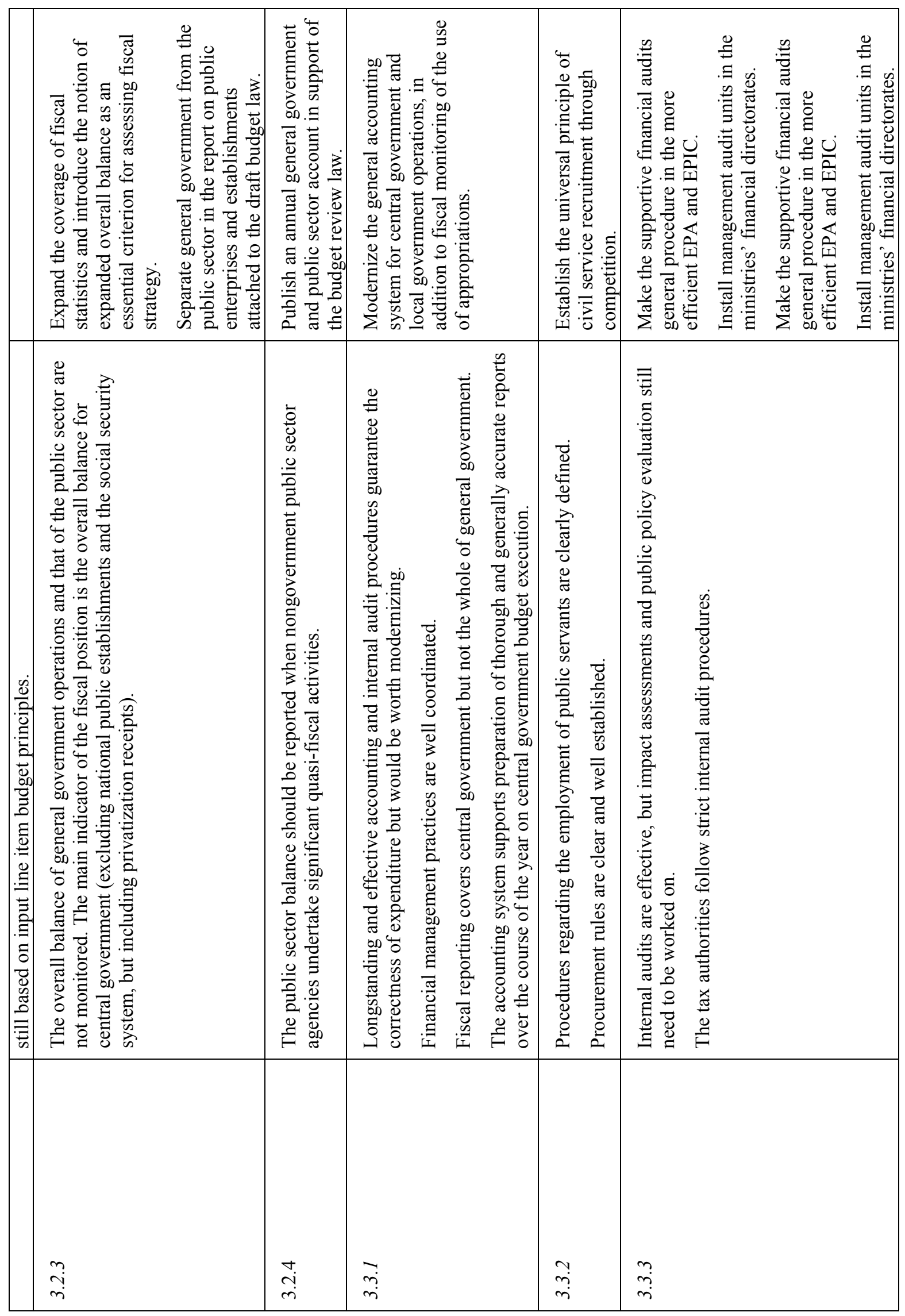




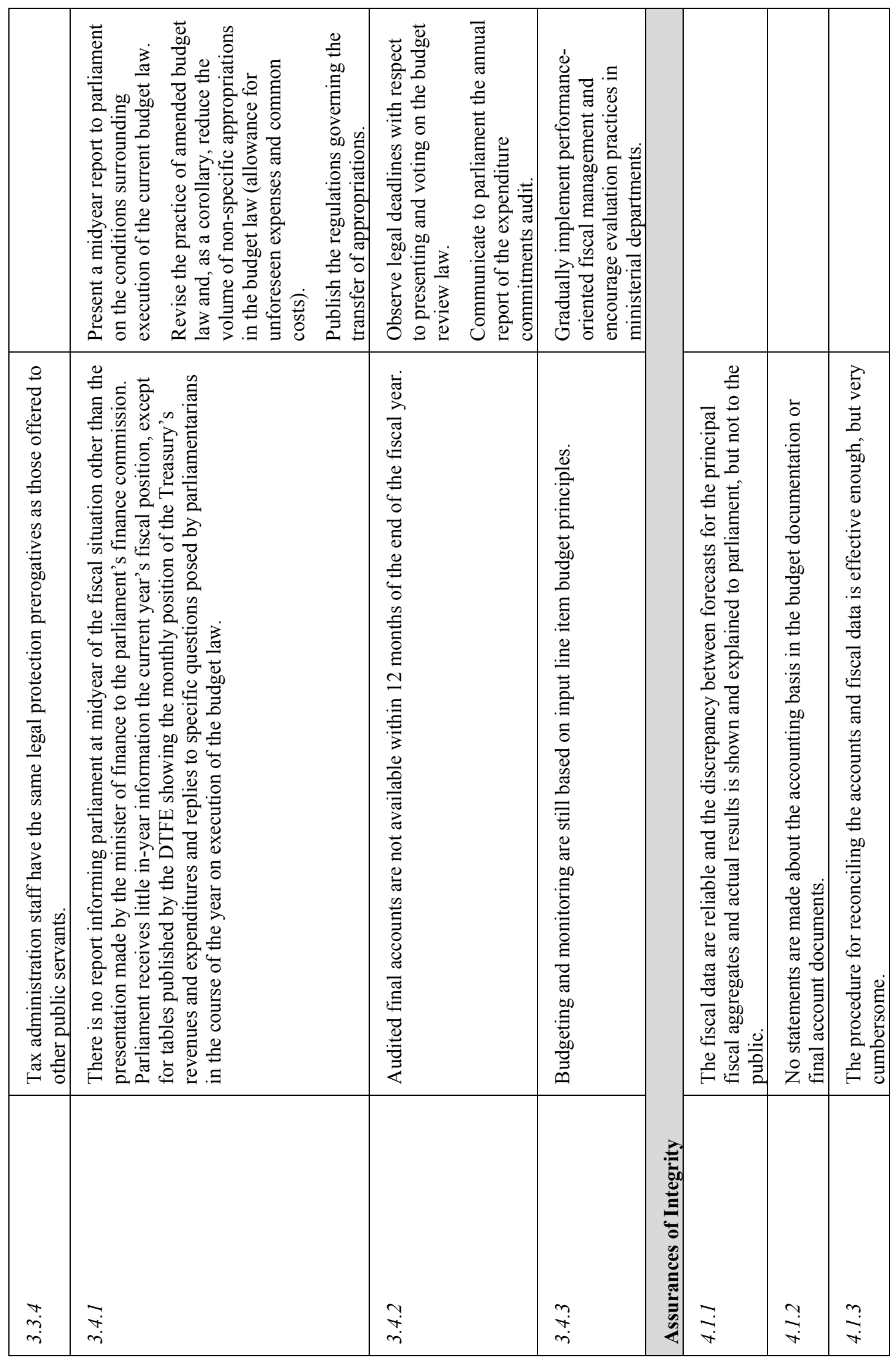




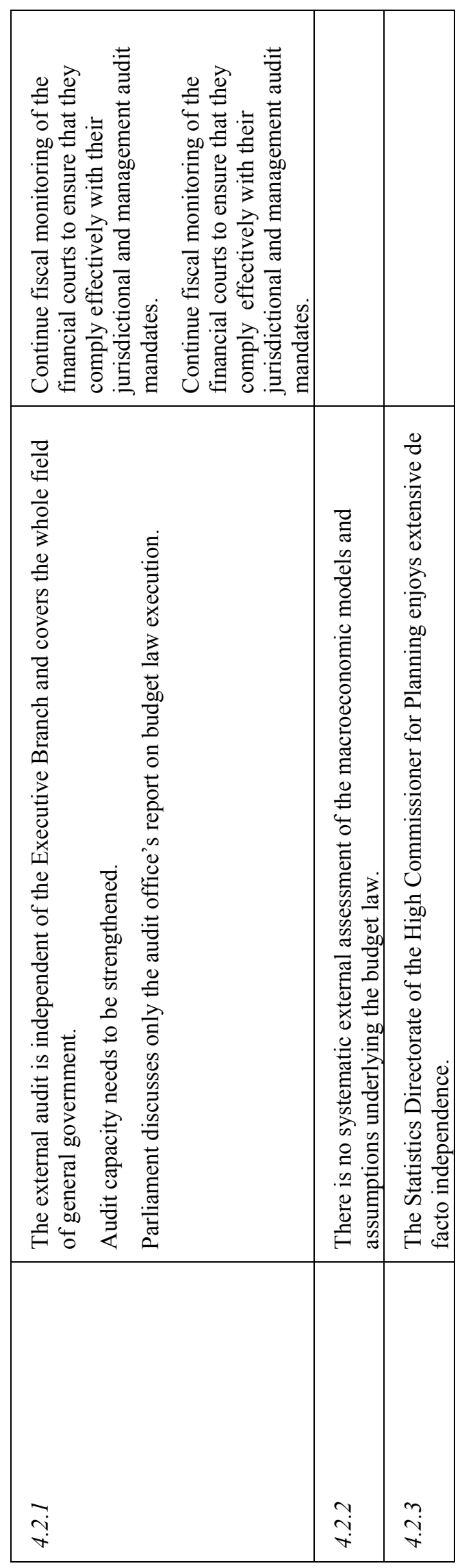




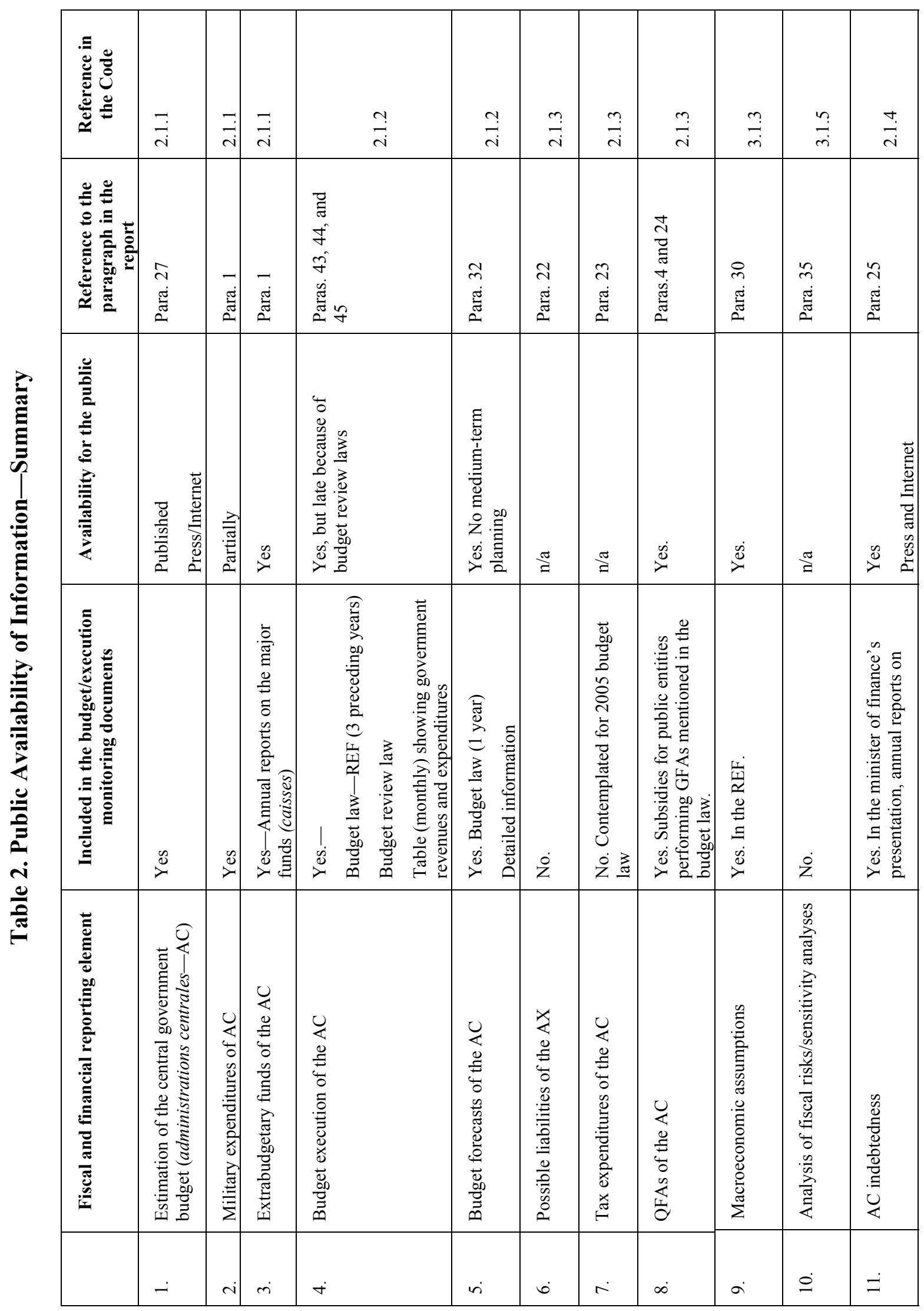




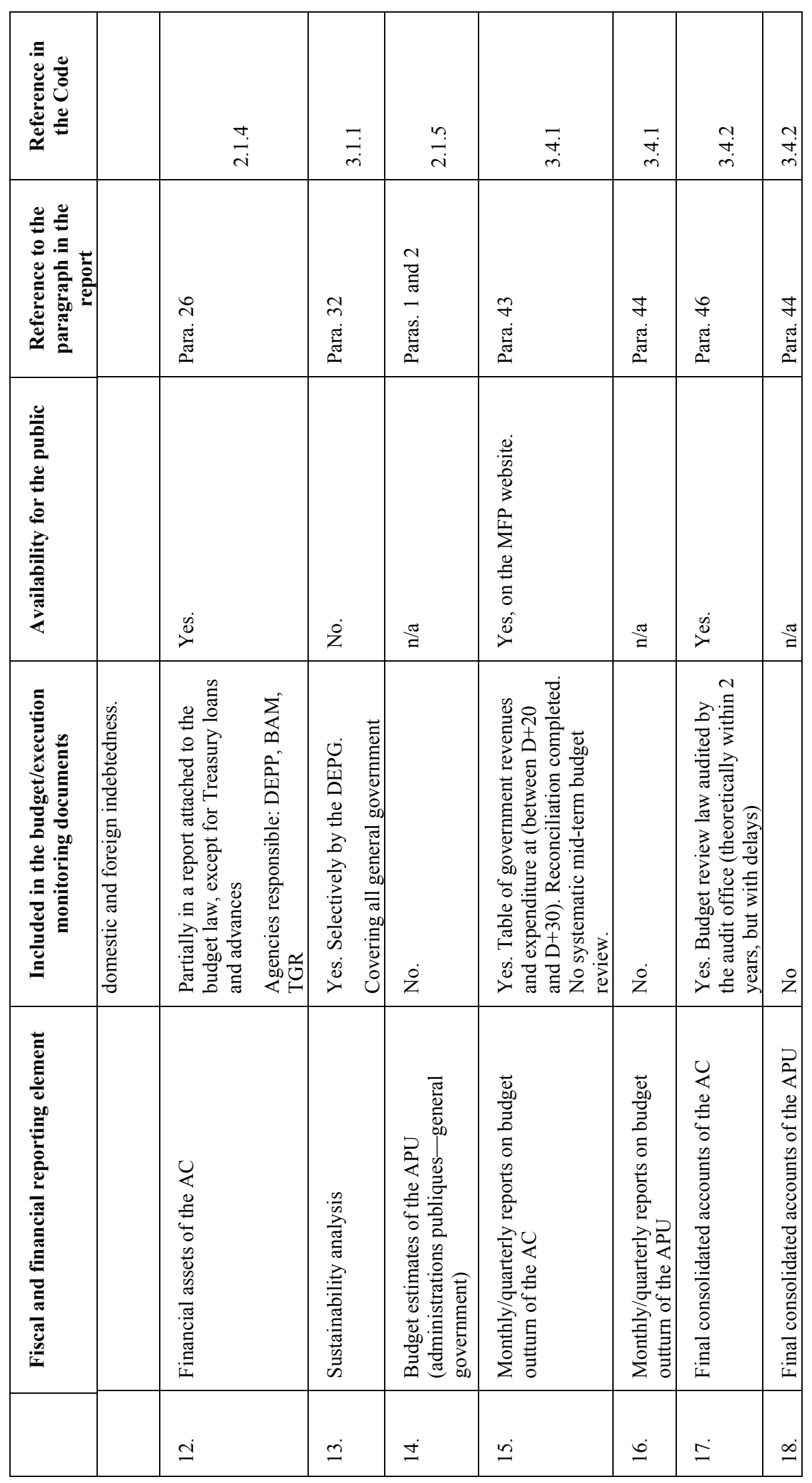

